\title{
Autophagy and thyroid carcinogenesis: genetic and epigenetic links
}

\author{
Federica Morani ${ }^{1}$, Rossella Titone ${ }^{1}$, Loredana Pagano ${ }^{2}$, Alessandra Galetto ${ }^{3}$, \\ Oscar Alabiso ${ }^{3}$, Gianluca Aimaretti ${ }^{2}$ and Ciro Isidoro' \\ ${ }^{1}$ Laboratory of Molecular Pathology, Department of Health Sciences ${ }^{2}$ Unit of Clinical Endocrinology ${ }^{3}$ Unit of \\ Oncology, Department of Translational Medicine, Università del Piemonte Orientale 'A. Avogadro', Via Solaroli 17, \\ 28100 Novara, Italy
}

Correspondence should be addressed to $\mathrm{C}$ Isidoro

Email

isidoro@med.unipmn.it

\begin{abstract}
Thyroid cancer is the most common cancer of the endocrine system and is responsible for the majority of deaths from endocrine malignancies. Although a large proportion of thyroid cancers belong to well differentiated histologic subtypes, which in general show a good prognosis after surgery and radioiodine ablation, the treatment of radio-resistant papillarytype, of undifferentiated anaplastic, and of medullary-type thyroid cancers remains unsatisfactory. Autophagy is a vesicular process for the lysosomal degradation of protein aggregates and of damaged or redundant organelles. Autophagy plays an important role in cell homeostasis, and there is evidence that this process is dysregulated in cancer cells. Recent in vitro preclinical studies have indicated that autophagy is involved in the cytotoxic response to chemotherapeutics in thyroid cancer cells. Indeed, several oncogenes and oncosuppressor genes implicated in thyroid carcinogenesis also play a role in the regulation of autophagy. In addition, some epigenetic modulators involved in thyroid carcinogenesis also influence autophagy. In this review, we highlight the genetic and epigenetic factors that mechanistically link thyroid carcinogenesis and autophagy, thus substantiating the rationale for an autophagy-targeted therapy of aggressive and radio-chemo-resistant thyroid cancers.
\end{abstract}
Key Words
$\checkmark$ autophagy
- thyroid cancer
- oncogenes
- epigenetics
- microRNA

\section{Introduction}

Thyroid cancer accounts for almost $90 \%$ of all endocrinerelated cancers, and is responsible for the majority of deaths from endocrine malignancies (Siegel et al. 2013). Thyroid cancers may arise from either the follicular (thyroid hormone-producing) or the parafollicular (calcitonin-producing) cells (Fig. 1). The large majority of follicular cell-derived thyroid cancers are well differentiated and are classified as papillary (about $80 \%$ of all thyroid cancers) or follicular thyroid cancer (PTC and FTC, respectively), and a minor portion show a poorly differentiated or undifferentiated (anaplastic) phenotype (named as poorly differentiated thyroid cancer (PDTC) and anaplastic thyroid cancer (ATC), respectively). Thyroid cancers arising from parafollicular cells, named medullary thyroid cancers (MTC), account for 3-5\% of all thyroid cancers. PTC is generally associated with favorable outcomes after surgery and radioactive iodine therapy, although $5 \%$ of these tumors show radio- and chemoresistance (Fassnacht et al. 2009, Grodski \& Delbridge 2009). On the other hand, ATC is extremely aggressive and soon leads the patient to death (Ain 1998, Smallridge 2012, Smallridge et al. 2012). MTC also have a generally

Published by Bioscientifica Ltd. 


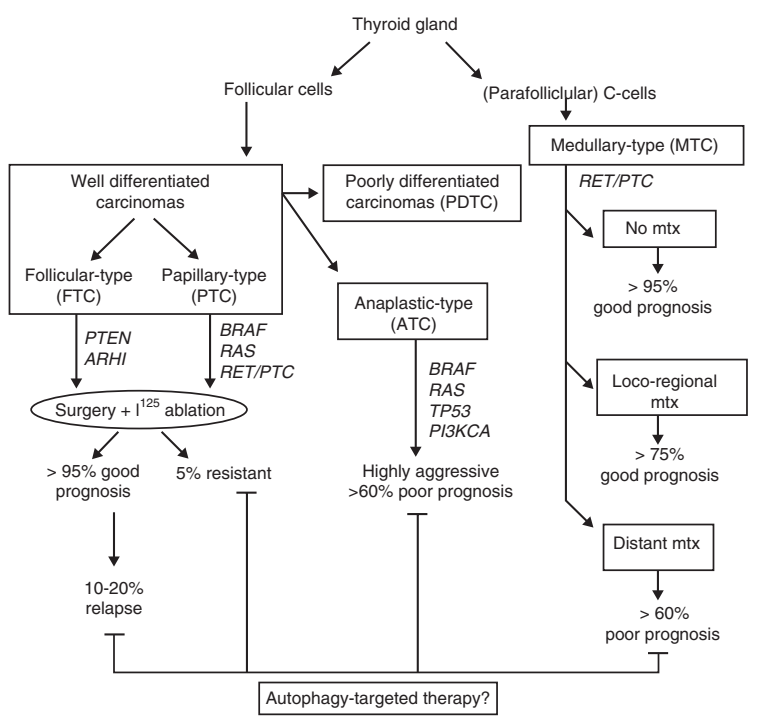

Figure 1

Autophagy-targeted opportunities for the therapy of thyroid cancers. Origin and aggressive phenotypes of thyroid cancers and opportunities for autophagy-targeted therapies. The main alterations in oncogenes and oncosuppressor genes in thyroid cancer histotypes are indicated in the boxes. C-cell, calcitonin-producing parafollicular cell; mtx, metastases.

good prognosis, with an overall survival rate at 10 years of $\sim 95 \%$ if the tumor is confined to the thyroid gland, which drops to $\sim 40 \%$ in the presence of metastases (Roman et al. 2006). Patients with an unresectable tumor or with distant metastases can be treated with chemotherapeutics (e.g., doxorubicin, 5-fluorouracil, cisplatin), yet the response rate is very low. Molecular therapy with inhibitors of mitogenic kinases has been disappointing, because it has not substantially improved the survival of patients with aggressive thyroid cancers, while showing an adverse sideeffect profile (Gild et al. 2011). For instance, the multikinase inhibitor vandetanib, which has been approved for the treatment of inoperable or metastatic MTC (Thornton et al. 2012), has shown a modest efficacy toward MTC progression, but an extremely toxic profile that includes gastrointestinal, cardiovascular, and neurological disorders (Chau \& Haddad 2013). Similarly, the results of a phase II clinical trials on the efficacy of the mammalian target of rapamycin (mTOR) inhibitor everolimus for the treatment of locally advanced or metastatic thyroid cancer have been disappointing (Lim et al. 2013). Thus, the lack of efficacious and safe treatment options provokes the search for novel molecular targeted drugs for the cure of such highly malignant thyroid cancers.

Recently, autophagy has emerged as a potential target for the therapy of hematologic and epithelial malignancies (Chen \& Karantza 2011, Gundara et al. 2012,
$\mathrm{Wu}$ et al. 2012). In vitro pre-clinical studies support the possibility of harnessing autophagy for the therapy of thyroid cancers (Lin et al. 2009, 2010, 2012a,b, Lu et al. 2012, Jin et al. 2013).

Autophagy (literally, 'self-eating') is the process through which damaged or redundant cytoplasmic constituents are degraded within lysosomes. Several oncogenes and oncosuppressor genes regulate the induction of autophagy. Autophagy is also epigenetically regulated through the methylation of autophagy regulatory genes, the activity of histone deacetylases (HDAC), and the expression of microRNAs (miRNAs). Here, we examine the genetic and epigenetic links between autophagy and thyroid carcinogenesis. A better understanding of such mechanistic connections could help to identify new targets for a more accurate diagnostic, prognostic, and therapeutic management of thyroid cancers.

\section{The autophagy machinery}

Macroautophagy is a vesicular-driven process through which protein macroaggregates, large portions of membranes, and entire organelles can be delivered to lysosomes for complete degradation. This process is distinct from chaperon-mediated autophagy and microautophagy in which, respectively, only a single protein at a time or a small amount of cytoplasmic material is internalized in the lysosome. Readers may refer to the many excellent reviews in which the morphological and biochemical features of these processes are described in detail (Orenstein \& Cuervo 2010, Yang \& Klionsky 2010, Mizushima \& Komatsu 2011, Sahu et al. 2011). Here, we will focus on macroautophagy (from now on simply named autophagy), as this is the major pathway contributing to the macromolecular turnover and cell homeostasis. In the following paragraphs, we briefly detail the key morphological and regulatory steps of autophagy.

\section{Morphological features and physiological significance}

Autophagy comprises the following principal steps: i) the formation of a vacuole, named the autophagosome, that entraps the cargo to be degraded; ii) the fusion of the autophagosome with endosomes and lysosomes that leads to the formation of an autophagolysosome; and iii) the degradation of the autophagy cargo (Fig. 2). The autophagosome is a double-layered vesicle that forms in the proximity of the trans-Golgi network. The progenitor membrane donor of the autophagosome is the smooth

Published by Bioscientifica Ltd. 
A

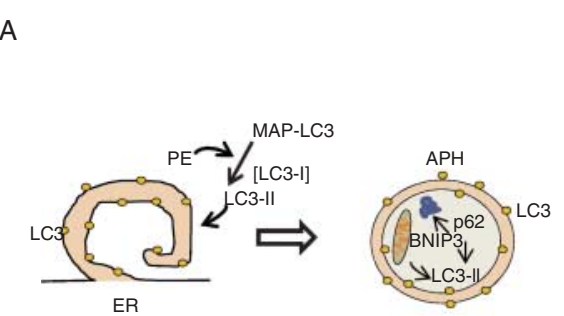

B

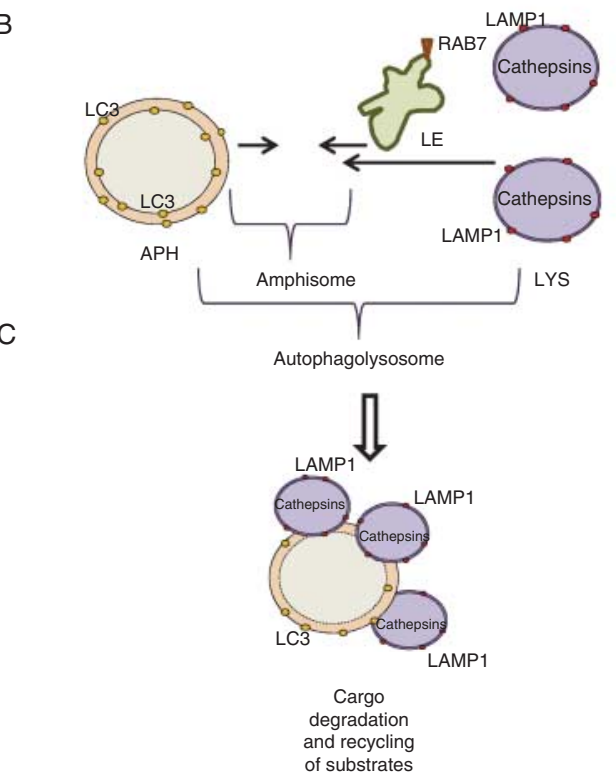
and recycling of substrates

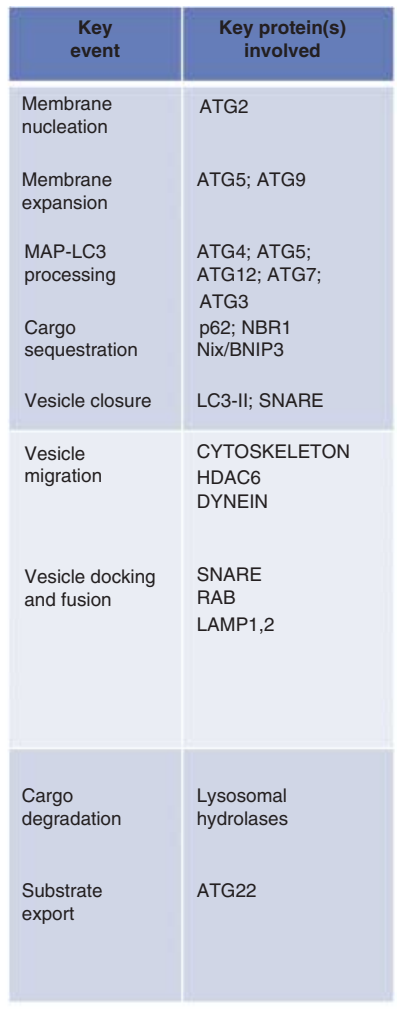

\section{Figure 2}

Morphological features of the (macro)autophagy process. The process can be dissected in three main steps. The key events and the relative protagonists of each step are indicated. (A) Formation of the autophagosomes (APH). Vesicle nucleation and membrane expansion start from the endoplasmic reticulum (ER). The autophagosome is marked by the presence on its internal and external membranes of LC3-PE, arising from MAP-LC3 (MAP-LC3, microtubule associate protein light chain 3; PE, phosphatydylethanolamine). The autophagy cargo includes portions of cytoplasm, protein aggregates, and mitochondrion, which are targeted by specific proteins such as p62, neighbor of BRCA1 (NBR1), and $\mathrm{Bcl}$ /adenovirus E1B 19-kDa interacting protein (BNIP3). (B) Fusion of the autophagosome with late endosomes (LE, identified by RAB7) to form an amphisome, and with lysosomes (LYS, identified by LAMP1) to

endoplasmic reticulum, though membranes from other sources, including the plasma membrane and the outer mitochondrial membrane, are subsequently recruited and contribute to the expansion of this vesicle (Ravikumar et al. 2010, Tooze \& Yoshimori 2010, Rubinsztein et al. 2012, Hamasaki et al. 2013). During this process, the lipidated form of light chain 3 (LC3, also known as ATG8) is post-translationally inserted into the expanding autophagosomal membrane through the intervention of several autophagy-related (ATG) proteins (Mizushima et al. 2011; form an autophagolysosome. This step requires HDAC6-mediated deacetylation of tubulin and the activity of dynein. Tethering of autophagosomes and lysosomes relies on soluble $N$-ethylmaleimidesensitive factor-attachment protein receptor (SNARE) proteins. (C) Degradation of autophagy cargo and recycling of substrates. In the autophagolysosome, the inner membrane of the autophagosome along with its cargo is degraded by lysosomal acid enzymes (essentially the cathepsins). This process is marked by the consumption of LC3 present in the inner membrane of the autophagosome. Substrates are then exported in the cytoplasm and recycled in the biosynthetic pathway. Full colour version of this figure available via http://dx.doi.org/ 10.1530/ERC-13-0271.

box in Fig. 2). The synthesis and membrane translocation of LC3II is considered an hallmark of autophagosome biogenesis (Klionsky et al. 2012). Autophagy substrates are specifically sequestered in the lumen of the nascent autophagosome through the intervention of proteins that bridge the substrate to LC3 in the internal membrane (Noda et al. 2010; box in Fig. 2). The autophagy process proceeds with the fusion of the autophagosome with several endosomes and lysosomes (at the end an autophagolysosomal vacuole is formed) and the subsequent full 
degradation of the autophagy substrates is conducted by lysosomal acid hydrolases (Eskelinen 2005). Finally, fully degraded substrates are exported to the cytoplasm and reutilized in biosynthetic pathways. It is to be stressed that autophagy has to proceed to completion to exert its prosurvival effects. The production of autophagosomes that do not completely fuse with lysosomes is of no benefit to the cell, because the autophagy substrates are not fully degraded and recycled, and may eventually become toxic. Therefore, to understand the pathophysiological outcome of autophagy, it is important to clearly determine the formation of autophagosome vs the autophagy flux (see section Detection of autophagy in thyroid cancer cells).

\section{Biochemical regulation of autophagy at a glance}

The induction and progression of autophagy are controlled by a complex network of signaling pathways that involve a number of protein- and lipid-kinases, proteinand lipid-phosphatases, and monomeric and trimeric

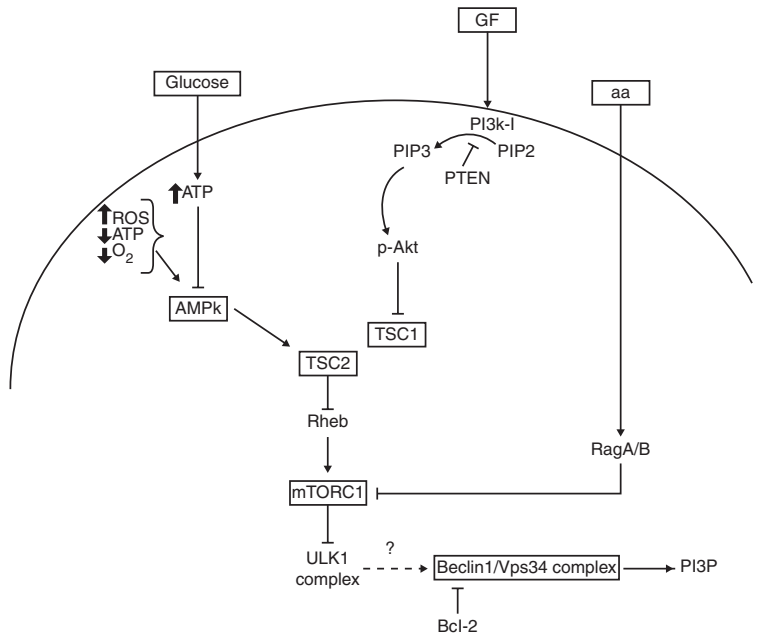

Figure 3

Biochemical regulation of the autophagy process. The scheme illustrates the main signaling pathways that control the induction of autophagy. Growth factors (GF) stimulate the activity of class I PI3k, which produces PIP3 and leads to activation of the AKT-mTOR axis. PTEN reduces the availability of PIP3, and therefore prevents the activation of the AKT-mTOR axis. Amino acids signal through the RagA/B pathway to keep mTOR active. The activation of mTORC1 negatively impinges on the ULK complex, thus inhibiting the induction of autophagy. In the absence of growth factors and of amino acids (starvation) this pathway is switched off, and mTOR is inactive, thus allowing the rise in the level of basal autophagy. The lack of glucose and of oxygen, as well as the presence of pro-oxidant species (e.g., ROS), activate the AMPk pathway, which results in the inhibition of mTOR and direct activation of the ULK complex and ultimately in the rise of autophagy. Largely unknown is the link between the ULK complex and the BECLIN1-Vps34 complex. The latter is inhibited when BCL2 binds to BECLIN1. Once activated, Vps34 produces PI3P.
GTPases (Mehrpour et al. 2010, Chen \& Klionsky 2011). The pathways illustrated in Fig. 3 represent an obvious, though efficacious, oversimplification. The master signal that triggers autophagy comes from the Unc51-like kinase 1 (ULK1, homolog of yeast Atg1) complex (Wong et al. 2013). Two upstream kinases, namely the mTOR-raptor complex 1 (mTORC1) and AMPk, control the activation of ULK1, the former acting as a repressor (Ganley et al. 2009, Jung et al. 2009) and the latter acting as an activator (Egan et al. 2011). mTORC1 integrates the signals from: i) the phosphatydilinositol-3-kinase (PI3k) class I/AKT pathway, which senses the presence of growth factors; ii) the AMPk pathway, which senses the lack of energy; and iii) the Rag A/B (a Ras-related GTPase) complex, which senses the availability of amino acids. In the presence of growth factors, the PI3k/AKT pathway negatively regulates autophagy through a tonic activation of mTORC1 via the tuberous sclerosis complex (TSC) and Rheb (Ras homolog enriched in the brain) (Petiot et al. 2000, Arico et al. 2001, Inoki et al. 2002). The lipid phosphatase activity of phosphatase and tensin homolog (PTEN) shuts down this pathway, thus abolishing the mTOR-mediated repression of ULK1. When amino acids are abundant, the RagA/B complex activates mTORC1 (Sancak et al. 2010), while the lack of amino acids is sensed by the RAS-BRAFERK1/2 pathway that triggers autophagy through the stimulation of heterotrimeric GTP proteins (Ogier-Denis et al. 1995, 2000). Glucose depletion and other metabolic stresses that reduce the production of ATP or provoke the production of reactive oxygen species (ROS) activates the AMPk pathway, that in turn represses mTORC1 and activates ULK1 (Alers et al. 2012), thus initiating autophagy (Alexander et al. 2010, Castino et al. 2011, Janda et al. 2012, Wong et al. 2013). Downstream to ULK1, class III PI3k (also known as Vps34) produces phosphatydil-3-phosphate (PI3P), the starting platform for the biogenesis of the autophagosome (Noda et al. 2010). Vps34 is activated through its interaction with Beclin1 (also known as ATG6 or Vps30) and p150 (homolog of Vps15), besides other regulating proteins (He \& Levine 2010). This pathway is impaired when Beclin1 is sequestered through the binding with BCL2 (Pattingre et al. 2005).

\section{Role of autophagy in cancer development and progression}

In quiescent and appropriately fed cells, autophagy runs at a constant basal level that ensures the homeostatic macromolecular turnover (Ravikumar et al. 2010), and it is

Published by Bioscientifica Ltd. 


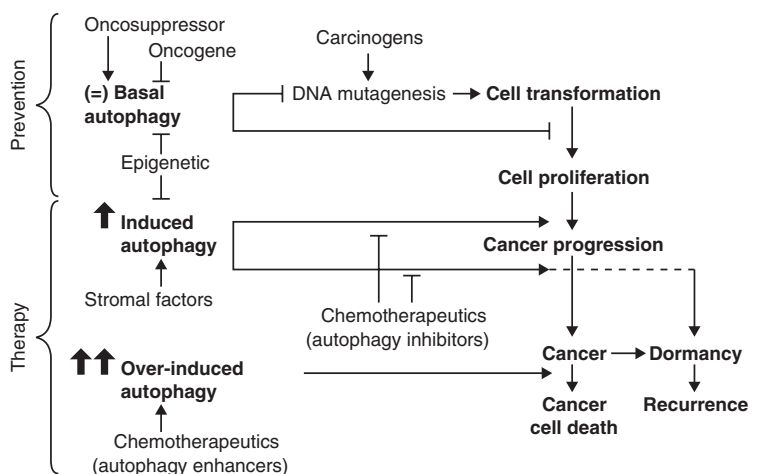

Figure 4

Double-face role of autophagy in the carcinogenic process and role of genetics and epigenetics in its regulation. Basal autophagy exerts a protective action in cells by eliminating molecules that could lead to DNA mutagenesis and cell transformation. Primitive mutations in certain oncogenes or oncosuppressors, as well as epigenetic regulation of certain autophagy-related genes, could limit the benefit of autophagy at this preventive step. Once cancer is established, autophagy may confer the advantage to cancer cells to face metabolic stresses (such as nutrient depletion, hypoxia, and chemotherapy-induced damages) and possibly to survive in a dormant state. At this stage, a chemotherapeutic regimen including autophagy-inhibiting drugs could elicit cancer cell death. On the other hand, chemotherapeutics that increases autophagy to a level beyond the point-of-no-return could also elicit cell death.

upregulated above the baseline when the lack of nutrients or of energy imposes the degradation of redundant selfconstituents to recover substrates and energy necessary for cell survival, or when it is necessary to eliminate a cell component that has been damaged by an extracellular insult (a toxic drug, radiation, or oxidative stress) (Kroemer et al. 2010, Ravikumar et al. 2010). Given these housekeeping functions, it is logical to suspect that autophagy is deregulated in cancer or, conversely, that deregulation of autophagy can promote carcinogenesis. However, the role of autophagy in cancer is not unequivocal, because, paradoxically, it may either prevent cell transformation or favor the survival of cancer cells, depending on how autophagy is regulated in the various steps of the carcinogenic process (White \& Di Paola 2009; Fig. 4). On one hand, autophagy opposes cell transformation by helping to get rid of mutagenic pro-oxidant molecules and by cooperating with the DNA repair system (Robert et al. 2011, Rodriguez-Rocha et al. 2011). Yet, this same process can turn to the advantage of cancer cells subjected to the genotoxic stress imposed by radiotherapy and chemotherapy. In addition, in growing tumors with defective vascularization there are areas in which the supply of nutrients and of oxygen is insufficient, and here autophagy is upregulated allowing cancer cells to survive despite the prohibitive metabolic conditions (Degenhardt et al. 2006), possibly in a dormant state (Lu et al. 2008). These cells resist to chemo- and radio-therapeutic treatments, and eventually give rise to cancer relapse. Further, a transient upregulation of autophagy is observed during the epithelial-mesenchymal transition (EMT; Akalay et al. 2013), and this function prevents the cell death by anoikis of cancer cells which have detached from the basement membrane to invade the extracellular matrix (Fung et al. 2008). Thus, autophagy is differently regulated during the carcinogenic process and its actual level in the cell could vary in subclones, depending on the acquisition of new oncogenic assets. The situation is far more complicated considering that autophagy is influenced by epigenetic factors (see below) and by extracellular factors such as oxygen, glucose, nutrients, growth factors, hormones, and cytokines.

From the above considerations it appears clear that autophagy has a great impact on the progression of tumors and on the response to therapeutic treatments, and therefore influences the prognosis. Consistently, certain autophagy-related proteins have been shown to be of prognostic value. For instance, the hyperexpression of BECLIN1 and of LC3 in general associates with a better prognosis in patients with glioblastoma (Pirtoli et al. 2009), colorectal cancer (Li et al. 2009, Koukourakis et al. 2010), lymphomas (Nicotra et al. 2010, Huang et al. 2011), or duodenal adenocarcinoma (Wu et al. 2013). Conversely, low expression of BECLIN1 or of LC3 associates with poor prognosis in patients with hepatocarcinoma (Ding et al. 2008), glioblastoma (Huang et al. 2010), colorectal cancer (Koukourakis et al. 2010), lymphoma (Nicotra et al. 2010), or lung carcinoma (Won et al. 2012).

\section{Autophagy and thyroid cancer}

A systematic study addressing the prognostic value of autophagy in thyroid cancers has not yet been performed. Still, some in vitro studies have proven the involvement of autophagy in the cytotoxic response of thyroid cancer cells to anti-tumor drugs (Table 1). In this section, we provide some technical tips for assessing the presence of autophagy in thyroid cancer biopsies and discuss the mechanistic links between autophagy and thyroid carcinogenesis.

\section{Detection of autophagy in thyroid cancer cells}

The expression of autophagy protein markers can be demonstrated in ex-vivo thyroid tumor tissue and in

Published by Bioscientifica Ltd 

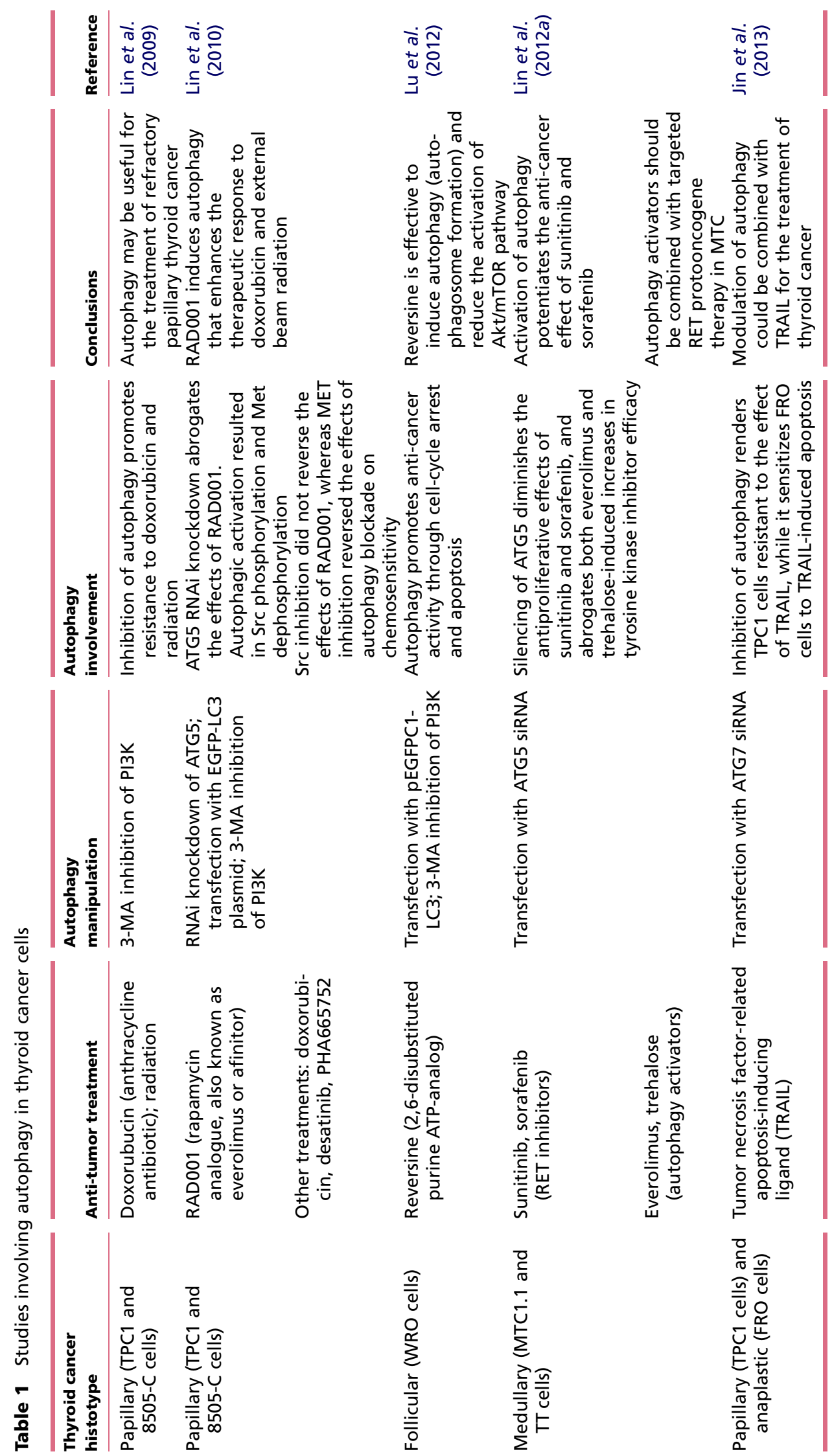

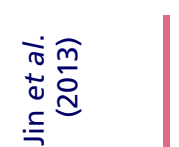
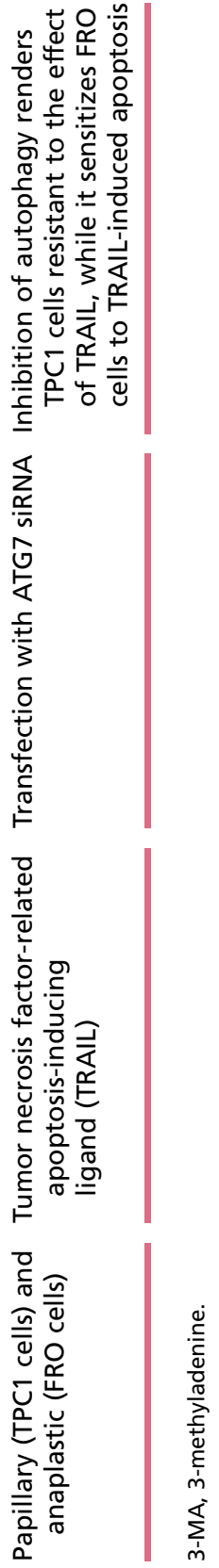
A Thyroid cancer tissue sections

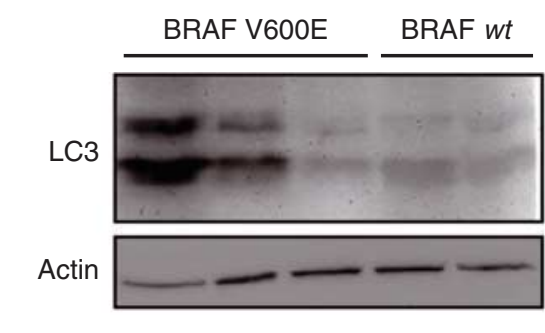

B

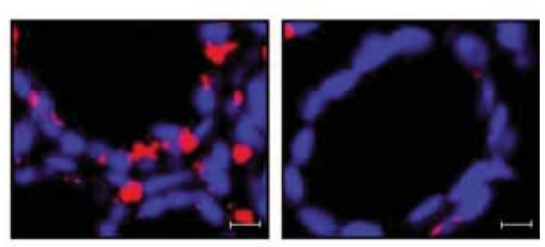

C Follicular thyroid cancer cells

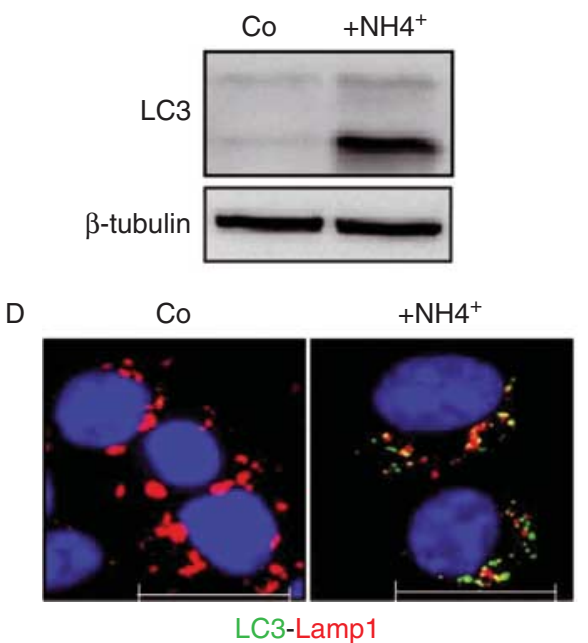

\section{Figure 5}

Detection of autophagy in thyroid cancer. Representative images showing the detection of markers of autophagy in thyroid cancer tissues and cells. (A and B) Analysis of the expression and accumulation of LC3 in thyroid cancer tissues. (A) Western blotting of LC3 in homogenates of frozen biopsies from BRAF-mutated and BRAF wt thyroid cancers. The presence of the LC3II isoform (lower band) is indicative of autophagy. In a preliminary study conducted on 19 cases ( 12 of which with mutated BRAF), we have not found a statistically significant correlation between the mutation of BRAF and the level of LC3II in thyroid cancer. (B) Immunofluorescence of LC3. The puncta in the cytoplasm of cancer cells are indicative of the presence of autophagosomes. (C and D) Expression of LC3 in cultured thyroid cancer cells (FTC133 cell line) incubated or not for $24 \mathrm{~h}$ with ammonium chloride $\left(\mathrm{NH}_{4}{ }^{+}\right)$. (C) Western blotting; (D) immunofluorescence co-staining of LC3 and LAMP1. It is evident the accumulation of LC3 in the cells incubated with ammonium chloride which in fact prevented the fusion of autophagosomes with lysosomes (as can be appreciated in panel D) and the degradation of LC3II (as can be appreciated in panel (C). Microscope magnification: (B) $40 \times$; (D) $63 \times$. Scale bars: (B) $10 \mu \mathrm{m}$; (D) $20 \mu \mathrm{m}$. Full colour version of this figure available via http://dx.doi.org/ 10.1530/ERC-13-0271. cultured thyroid cancer cells. Paraffin-embedded and cryostatic tissue sections can be processed for immunohistochemistry and immunofluorescent detection of autophagy markers, while western blotting analysis is better performed in freshly isolated or frozen biopsy tissues. Both these techniques are complementary and should be employed.

As an example, we report our preliminary observations on the detection of autophagy markers in tissue biopsies and in cultured cells of thyroid cancer origin. Western blotting of LC3 reveals the presence of the autophagosome-bound LC3II isoform, which arises from LC3I (Fig. 5A and C). One important caveat is that infiltrating fibroblasts, macrophages, and mastocytes might also express autophagy markers. This should be taken into consideration when performing a western blot with the whole homogenate of a biopsy, unless cancer cells are isolated by laser microdissection. In immunofluorescence, nontumor cells can be discriminated by using appropriate markers for stromal cells. A faintly detectable diffuse cytoplasmic signal of LC3 is considered as negative background, while a pattern of many LC3positive puncta (in general, more than 10 per cell) is indicative of ongoing autophagy (Fig. 5B and D). Immunocostaining with multiple markers (e.g., LC3, p62, BECLIN1, lysosome-associated membrane protein (LAMP1)) is recommended for a better assessment of the autophagy flux and of the signaling molecules involved. The true level of ongoing autophagy is much easier assayed in cultured cells through the pharmacologic or genetic manipulation of the autophagy flux. For instance, in the presence of drugs that alkalinize the lysosome $\mathrm{pH}$ (e.g. ammonium chloride) all the autophagosomes produced during the incubation time accumulate in the cell as they do not fuse with lysosomes (Kawai et al. 2007, Klionsky et al. 2012), and this reflects in the accumulation of LC3II protein (Fig. 5C and D).

\section{The genetic connection: oncogenes and oncosuppressor genes}

Numerous oncogenes and tumor suppressor genes regulate autophagy (Maiuri et al. 2009). In general, oncogenic proteins exert a negative activity and oncosuppressor proteins exert a positive activity on autophagy induction and progression. Several oncogenes and oncosuppressors implicated in thyroid carcinogenesis also play a role in the regulation of autophagy.

The main signaling pathways that link thyroid carcinogenesis with autophagy deregulation are the

Published by Bioscientifica Ltd. 
RAS-RAF-ERK and the class I PI3k-AKT-mTOR pathways. The RAS/RAF/MEK/ERK pathway controls the mTORdependent pathway by sensing the absence of amino acids (Ogier-Denis et al. 2000). Aberrant signaling through the RAS/RAF/MEK/ERK cascade has been implicated in thyroid tumor initiation and development. For instance, the RET/PTC rearrangement, which leads to the RET/PTC fusion oncoprotein, activates the RAS-RAF-MAPK cascade (Knauf et al. 2003, Santoro et al. 2004). However, the most frequent aberration of this signaling pathway in thyroid cancer is associated with the oncogenic activation of BRAF. The BRAF V600E mutation, which leads to constitutive activation of BRAF kinase, is frequently found in PTC (Xing 2007) and, though less frequently, also in ATC (Nikiforova et al. 2003, Takano et al. 2007) and PDTC (Begum et al. 2004). In melanomas, oncogenic BRAF has been associated with inhibition of mTOR and upregulation of basal autophagy (Maddodi et al. 2010). However, another study showed that in metastatic melanomas oncogenic BRAF opposed the induction of autophagy by chemotherapeutics or rapamycin (Armstrong et al. 2011). Another oncogene of this same pathway which is mutated in a large percentage of thyroid cancers is the RAS oncogene (Motoi et al. 2000, Nikiforova \& Nikiforov 2009). Activating mutations of RAS are associated with aggressive phenotypes of thyroid cancer and poor prognosis (Garcia-Rostan et al. 2003). Remarkably, the oncogenic mutants Ha-RAS and K-RAS have been shown to confer a metabolic advantage to cancer cells through the upregulation of basal autophagy (Guo et al. 2011, Kim et al. 2011). The above findings on the effects of active BRAF and Ha-RAS on autophagy seem to contradict the general rule that oncogenes signal to downregulate autophagy. Besides the fact that basal and stress-induced autophagy should be distinguished, it is likely that the true effect of oncogenic BRAF and RAS on autophagy regulation is cell context dependent and also reliant on the extracellular trigger. In addition, it should be considered that oncogenic RAS can signal through either the RAF-MEK-ERK1/2 pathway or the PI3K/AKT pathway, with a different impact on the regulation of autophagy (see below). Therefore, the final outcome on autophagy regulation by oncogenic RAS will depend on which downstream pathway will predominate.

The class I PI3k-(PTEN)-AKT-mTOR pathway is the other oncogenic pathway aberrantly hyperactive in thyroid cancer cells and is also known to regulate autophagy (see Fig. 3). Growth factors activate class I PI3k, which then phosphorylates phosphatidylinositol3,4-diphosphate into phosphatidylinositol-3,4,5- triphosphate (PIP3), the phosphate donor needed for the phosphorylation of AKT. Active AKT then phosphorylates a number of downstream targets that ultimately regulate various cellular functions, including cell survival, proliferation, autophagy, protein synthesis, angiogenesis, and migration. Genetic alterations in the PI3k/AKT signaling pathway have been linked to thyroid cancers (Garcia-Rostan et al. 2005, Shinohara et al. 2007, Wang et al. 2007). The PIK3CA gene (encoding the catalytic subunit of p110 $\alpha$ of class I PI3k) has been found amplified or mutated in thyroid carcinomas (Wu et al. 2005, Wang et al. 2007). Increased AKT activity has been associated with the aggressive behavior of FTCs and PTCs (Ringel et al. 2001, Shinohara et al. 2007). AKT negatively regulates autophagy through the mTOR pathway (Arico et al. 2001, Castino et al. 2008) and, directly, through phosphorylation of BELCIN1 (Wang et al. 2012). The class I PI3k/AKT pathway may be abnormally upregulated as a consequence of PTEN loss-of-function. The lipid phosphatase activity of PTEN removes the phosphate in position 3 from PIP3, thus limiting the availability of PIP3 needed for the activation of AKT. By shutting down the activation of AKT, PTEN relieves the AKT-mTOR block on autophagy (Arico et al. 2001). It is worth noting that mutations or deletions of the tumor suppressor gene PTEN have been recognized as an important step in the development of thyroid gland carcinomas (Dahia et al. 1997, Eng 2002).

Another oncogene that might link autophagy deregulation with thyroid carcinogenesis is c-MET. This proto-oncogene encodes a membrane tyrosine kinase receptor for the hepatocyte growth factor (HGF), which is a potent mitogen for epithelial cells and promotes cell motility and invasion in carcinoma cells (Stella et al. 2010). A large cohort study revealed that about $50 \%$ of PTCs are characterized by MET overexpression (Di Renzo et al. 1992), and this represents a sign of more aggressive disease (Ramirez et al. 2000, Mineo et al. 2004). Very recently, it has been shown that c-MET overexpression or its activation by HGF negatively regulates autophagy in A549 carcinoma cells (Liu et al. 2012). In the context of thyroid cancer, it has been reported that induction of autophagy by RAD001-mediated inhibition of mTOR sensitized PTC cells to chemo- and radio-therapy through the inhibition of c-MET (Lin et al. 2010).

What about other tumor suppressors, besides PTEN, that are deleted or mutated in thyroid cancers and might play a role in the regulation of autophagy?

The haplo-insufficient tumor suppressor gene BECLIN1 was the first oncosuppressor gene that proved the link between autophagy and cancer susceptibility

Published by Bioscientifica Ltd 
(Liang et al. 1999, Qu et al. 2003, Yue et al. 2003). BELCIN1 has been found mutated or monoallelically deleted in a large proportion of a variety of epithelial cancers, including breast and ovary carcinomas (Qu et al. 2003, Yue et al. 2003). Predictably, similar gene alterations could also be found in thyroid cancers. However, as yet no studies have addressed this issue.

The other tumor suppressor that may link autophagy and thyroid cancer progression is p53. Contrary to what is seen in many other cancers, TP53 loss-of-function mutations occur late in thyroid tumorigenesis. TP53 mutations are practically absent in differentiated thyroid cancers, while their prevalence is high (17-38\%) in PDTC and is even higher (55-88\%) in ATC (Fagin \& Mitsiades 2008, Smallridge et al. 2009). The regulatory activity of p53 in the autophagy pathway is quite ambiguous (Maiuri et al. 2010). As a transcription factor, wild-type p53 promotes autophagy by directing the transcription of certain autophagy genes, including damage-regulated autophagy modulator (DRAM) and ULK1/2 (Crighton et al. 2006, Gao et al. 2011). However, in many different cell types the lack of p53 has been shown to stimulate the autophagic flux, suggesting an inhibitory function of this tumor suppressor. In line with this finding, certain DNA-binding deficient p53 mutants that fail to relocate to the nucleus, and instead reside in the cytoplasm, have been shown to repress the induction of autophagy by metabolic stresses.

The ras-homolog GTPase aplasia Ras homolog member I (ARHI) (or DIRAS3) is another oncosuppressor that potentially links autophagy to thyroid carcinogenesis. ARHI positively regulates the autophagy-mediated dormancy of tumor cells (Lu et al. 2008). Of interest, ARHI is found underexpressed in FTCs (Weber et al. 2005).

\section{The epigenetic liaisons: the role of DNA methylation, histone deacetylates, and miRNAs}

Epigenetics refers to heritable (i.e., transmitted via meiosis or mitosis) changes in the expression of a gene or a set of genes not dependent on variations in the primary DNA sequence. Given that all cells in the same organism bear the same genome, epigenetics explains the different cellular phenotypes in the body as a result of the silencing of different subsets of genes. It is now clear that epigenetics plays a role in cancer, as cancer cells have their own epigenome. During cell proliferation, the epigenome is transmitted to daughter cells, although novel epigenetic signatures may emerge in the progeny as a consequence of (micro)environmental interference, thus explaining the appearance of clones with different behavior in the context of the tumor (Timp \& Feinberg 2013). There are four epigenetic mechanisms known to regulate gene expression: DNA methylation in correspondence to the promoter region, histone conformation changes (essentially dictated by acetylation and deacetylation of certain lysine residues), chromatin remodeling (both histone conformation changes and chromatin remodelling affect DNA accessibility), and miRNAs (short, noncoding mRNAs that impair RNA translation by hybridizing to specific domains of the UTR of target mRNAs).

In recent years, a large body of evidence has accumulated showing the pivotal role of epigenetic changes in thyroid tumorigenesis driven by DNA methyl transferases (DNMTs), HDAC, and miRNAs (reviewed in Pallante et al. (2010), Braun \& Hüttelmaier (2011), Russo et al. (2011) and Catalano et al. (2012a)). In this section, we provide a brief overview of the proteins and of the mechanisms involved in the epigenetic regulation in thyroid cancer that also have an impact on the regulation of autophagy.

For instance, the hypermethylation of the PTEN promoter region sporadic thyroid cancers has been reported (Alvarez-Nuñez et al. 2006). The lack of PTEN expression maintains active AKT in thyroid cancer cells, and consequently autophagy in these cells will be repressed.

The promoter of death-associated protein kinase (DAPk) has also been found to be hypermethylated in a large proportion of thyroid cancers (Hoque et al. 2005). This kinase induces autophagy by disrupting the BECLIN1-BCL2 complex (Zalckvar et al. 2009), and its epigenetic silencing in thyroid cancer cells might impair the induction of autophagy under stress conditions.

An intriguing epigenetic liaison between autophagy and thyroid carcinogenesis could involve the tumor suppressor ARHI, a Ras homolog that was recently shown to induce autophagy and autophagy-mediated dormancy in ovarian cancer cells (Lu et al. 2008). ARHI is generally monoallelically expressed (from the paternal allele), as the maternal allele is inherited in the hypermethylated (and therefore silenced) state. ARHI maps to $1 \mathrm{p} 31$, a region that is frequently deleted in thyroid cancers, particularly in FTCs (Weber et al. 2005). It has been hypothesized that silencing of ARHI expression, as a result of combined hypermethylation of the maternal allele and deletion of the paternal allele, is pivotal to thyroid carcinogenesis (Weber et al. 2005).

Histone deacetylation promoted by HDACs negatively affects gene transcription. There is evidence that certain HDACs (namely SIRT1, HDAC1, HDAC2, HDAC6) can

Published by Bioscientifica Ltd. 
regulate the autophagy process at the level of gene transcription and of protein function (Moresi et al. 2012, True \& Matthias 2012, Füllgrabe et al. 2013). As histone deacetylation decreases DNA accessibility, the inhibitors of HDACs promote gene transcription. Indeed, the treatment with the HDAC inhibitor suberoylanide hydroxamic acid was shown to induce autophagy in several cell types (Shao et al. 2004, Gammoh et al. 2012). There is promising evidence that HDAC inhibitors can be used in combination with other chemotherapeutics to improve their effectiveness in the treatment of thyroid cancers. HDAC inhibition was shown to increase the expression of E-cadherin, thus promoting cell-cell adhesion and reducing the migration of in vitro cultured thyroid cancer cells (Catalano et al. 2012b). E-cadherin is downregulated during the EMT process that precedes the metastasization of cancer cells, and, it is worth noting, the actual level of autophagy in cancer cells increases at this step in concomitance with E-cadherin silencing (Akalay et al. 2013). Whether the reexpression of E-cadherin following HDAC inhibition also associates with repression of autophagy in thyroid cancer cells has yet to be proven. Besides histones, some HDACs also deacetylate target cytoplasmic proteins, among which are also some proteins involved in the initiation and progression of autophagy (Lee et al. 2008, 2010, Lin et al. 2012a,b, Yi et al. 2012). For instance, SIRT1 deacetylates ATG5, ATG7, and ATG8 (Lee et al. 2008), which are essential for the formation of autophagosomes, while HDAC6 deacetylates the cytoskeletal protein tubulin, thus favoring the fusion of autophagosome with lysosomes (Lee et al. 2010).

The third epigenetic mechanism that potentially links autophagy and thyroid cancer are the miRNAs, a class of noncoding RNAs of 20-24 nucleotides that control gene expression at the post-transcriptional level (Ghildiyal \& Zamore 2009). The link between miRNAs and epigenetics is bidirectional, as on one hand the expression of miRNAs is dictated by the methylation and acetylation status of DNA, and on the other hand miRNAs themselves regulate the expression of DNMTs and HDACs (Iorio \& Croce 2009). For simplicity, we will only refer to those miRNAs that interfere with the expression of proteins involved in the regulation of autophagy and that are abnormally expressed in thyroid cancers.

Several miRNA profiling studies have identified changes in miRNA patterns occurring during thyroid cancer development and progression, opening a new field for the understanding of this disease and providing improved diagnostic, prognostic, and therapeutic approaches (reviewed in Pallante et al. (2010), Braun \&
Hüttelmaier (2011), De la Chapelle \& Jazdzewski (2011) and Gundara et al. (2012)). Autophagy in itself, as a metabolic process regulated by an intricate network of proteins, is regulated by miRNAs at various levels (Gundara et al. 2011, Frankel \& Lund 2012, Zhai et al. 2013). In principle, any miRNA targeting a signaling pathway involved in the control of autophagy would exert its regulatory activity on this pathway. For instance, miR221/222 and miR21, which target PTEN and consequently sustain the hyperactivation of AKT (Garofalo et al. 2009, Chun-Zhi et al. 2010), indirectly have a negative impact on induction of mTOR-dependent autophagy. With relevance to the present context, miR21 was found upregulated in PTCs and ATCs (Braun et al. 2010, Frezzetti et al. 2011), and miR221/222 cluster was found to be upregulated in PTCs (He et al. 2005, Pallante et al. 2006, Visone et al. 2007, Sheu et al. 2010). The loss of miR200 expression marks the progression of thyroid carcinomas culminating in tumor growth factor beta (TGF $\beta$ ) dependent EMT and elevated invasiveness (Braun et al. 2010). Members of the miR200 family (comprising miR141, 200a, 200b, 200c, and 429) are potent suppressors of EMT through the downregulation of the expression of EMT-promoting factors like ZEB1, ZEB2, SNAI2, SMAD2, TGF $\beta$ R1, and TGF $\beta 2$, and by antagonizing the transcriptional repression of E-cadherin (Gregory et al. 2008, Park et al. 2008, Braun et al. 2010). Of note, the actual level of autophagy in cancer cells was found to increase during EMT in concomitance with E-cadherin downregulation (Akalay et al. 2013). Thus, one can hypothesize that in thyroid cancer cells with low-levels of miR200, autophagy is upregulated to oppose anoikis in invading cells.

More recently, miRNAs specifically targeting the mRNA of autophagy proteins are being identified. Here, we will mention only those miRNAs involved in both the regulation of autophagy and the progression of thyroid cancers. The first miRNA described in this field is miR30a, which downregulates the expression of Beclin1 (Zhu et al. 2009). In the same family, miR30d was shown to target the mRNA of various autophagy proteins including BECLIN1, Bcl2/adenovirus E1B 19-kDa interacting protein (BNIP3L, which plays a role in mitophagy), ATG2, ATG5, and ATG12 (Yang et al. 2013). miR30a and miR30d were found to be expressed at a low-level in PTCs (Tetzlaff et al. 2007) and at a very low-level in ATCs (Schwertheim et al. 2009), respectively. It is intriguing to note that the miR30 family also antagonizes TGF $\beta$-induced EMT and in vitro invasiveness of ATC-derived cells (Braun et al. 2010). miR130a, one of the most significantly downregulated miRNAs in thyroid cancer cells with BRAF mutation (Cahill et al. 2007),

Published by Bioscientifica Ltd 


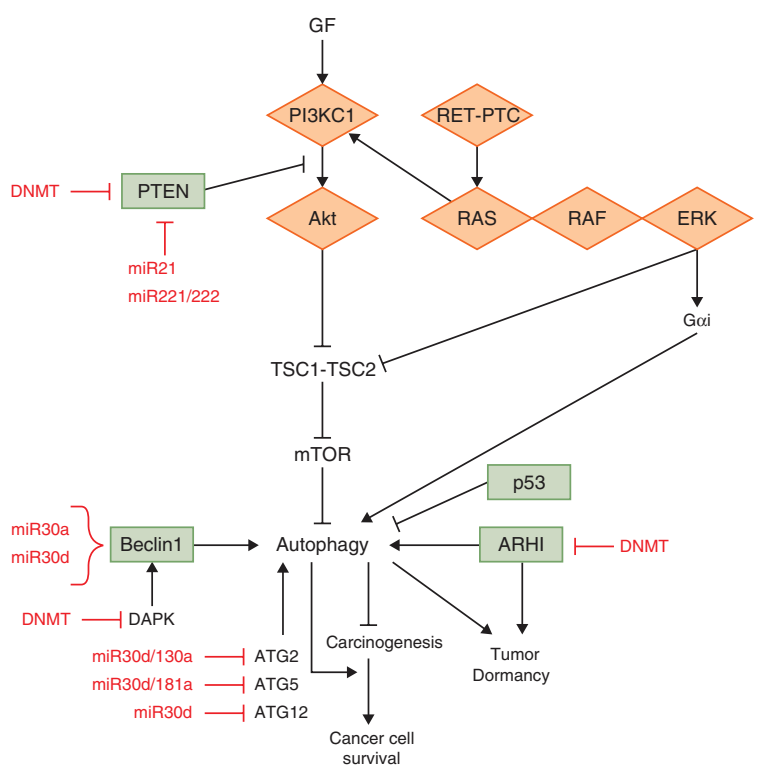

Figure 6

Genetic and epigenetic links between thyroid carcinogenesis and autophagy regulators. The scheme summarizes the potential links between autophagy and thyroid cancer progression at both genetic and epigenetic levels. Oncogenes are represented by rhombus and oncosuppressor genes by rectangles. Epigenetic regulations by DNMTs and miRNAs are indicated. $\mathrm{GF}$, growth factor. Full colour version of this figure available via http://dx. doi.org/10.1530/ERC-13-0271

is known to downregulate the expression of ATG2B (Kovaleva et al. 2012), while miR181a, which is expressed at a very low level in the presence of RET/PTC1 rearrangement (Cahill et al. 2006), is known to downregulate ATG5 (Huang et al. 2012, Tekirdag et al. 2013). Finally, miR183 was recently shown to negatively regulate the expression of LC3 in MTC cells (Abraham et al. 2011).

The scheme in Fig. 6 summarizes the potential links between autophagy and thyroid cancer progression at both genetic and epigenetic levels.

\section{Can we exploit autophagy for the therapy of thyroid cancers?}

Autophagy-targeted therapy is nowadays considered a valuable strategy to combat radio- and chemo-resistant cancers (Chen \& Karantza 2011, Yang et al. 2011, Gundara et al. 2012). Accumulating experimental data suggest that the efficacy of such therapies is strictly dependent on the actual level of ongoing autophagy in tumor cells, which is dictated by both genetic mutations and epigenetic phenomena, besides the dynamic influence of the tumor microenvironment.

The first report suggesting the involvement of autophagy in the response to therapeutic treatments of thyroid cancer dates back only a few years. Lin et al. (2009) found that both doxorubicin and radiation induced autophagy and cell death in cultured PTC cells. As the inhibition of Vps34-mediated autophagy by 3-methyl adenine increased the resistance toward these treatments, these authors concluded that autophagy was instrumental to cell toxicity in both treatments.

With regard to the therapy of thyroid cancer, besides radiation, new molecular therapies are emerging which employ kinase inhibitors, proteasome inhibitors, and epigenetic modulators (Catalano et al. 2010), and some of these drugs have been shown to also affect the autophagy process. For instance, sorafenib and sunitinib, two small molecules that inhibit the activity of RET kinase and that are commonly used for the treatment of MTCs, were shown to induce autophagosome accumulation in MTC cultured cells (Lin et al. 2012a,b). Apoptosis of MTC cells induced by these two drugs was abrogated when the essential autophagy protein ATG5 was silenced, and conversely it was enhanced when autophagy was concomitantly upregulated by co-treating with the mTOR inhibitor, everolimus (Lin et al. 2012a,b). Everolimus and other mTOR inhibitors are being tested for their potential efficacy against thyroid cancers (Gild et al. 2013, Lim et al. 2013). Everolimus is a rapamycin analog and it was introduced to the clinical management of epithelial cancers because of its ability to halt the biosynthetic and proliferative pathways downstream of the AKT-mTOR axis, but it is now recognized that rapamycin analogs may also elicit their beneficial effects via induction of autophagy. Consistently, sensitization of PTC cells to doxorubicin and radiotherapy by everolimus (known also as RAD001) was shown to strictly depend on autophagy (Lin et al. 2010).

Statins, when used for the treatment of thyroid cancers, may also act through the induction of autophagy. In a study, a xenograft of ATC in mice was successfully treated by combining paclitaxel, a cytoskeleton disrupting agent, with combretastatin A4 phosphate, a vascular-inhibiting drug, and it was found that the latter drug induced autophagy in cancer cells, besides inducing apoptosis of endothelial cells (Yeung et al. 2007). In addition, rosuvastatin, a statin with antiproliferative activity, was shown to induce autophagy and to promote the switch from pro-survival to pro-death autophagy in PTC cells (Zeybek et al. 2011).

Further, reversine, a synthetic purine analog with promising therapeutic potential, has recently been shown to induce growth arrest and apoptosis in FTC cells through the induction of autophagy (Lu et al. 2012).

Published by Bioscientifica Ltd. 
More recently, autophagy was shown to mediate the resistance to apoptosis induced by tumor necrosis factorrelated apoptosis inducing ligand (TRAIL) in PTC and ATC cells (Jin et al. 2013).

As for epigenetic modulators, the use of HDAC inhibitors for autophagy therapy in cancer has been proposed (Yang et al. 2011). The HDAC inhibitor valproic acid (VPA) has been successfully employed in a combination therapy in ATC (Noguchi et al. 2009). VPA sensitized ATC cells to paclitaxel (Catalano et al. 2007) and to doxorubicin (Catalano et al. 2006). The small molecule lithium chloride was shown to synergize with VPA to inhibit the growth of in vitro cultured MTC cells (Adler et al. 2010). It is interesting to note, in this context, that lithium chloride is an inducer of mTOR-independent autophagy (Fornai et al. 2008), and that VPA, by inhibiting HDAC6, negatively interferes with the formation of the autophagolysosome (Lee et al. 2010).

Demethylating agents could also work in this manner. For instance, decitabine ( 2 '-deoxy-5-azacytidine) has been shown to favor apoptosis by conventional chemotherapeutics in leukemic cells through the hyperinduction of autophagy (Schnekenburger et al. 2011).

Finally, in the near future we might be able to exploit miRNA-targeting autophagy for the cure of thyroid cancers (Gundara et al. 2012).

\section{Concluding remarks}

The paradoxical role of autophagy in cancer development and progression has important clinical implications in therapy, because it suggests that autophagy-inducer drugs may have benefits in preventing the development and growth of cancer cells while autophagy-inhibitor drugs should improve the efficacy of anti-cancer therapies in developed and metastatic cancers. Indeed, both proand anti-autophagy therapeutic drugs have shown their efficacy in in vitro and in vivo models of cancer, as well as in clinical trials (Chen \& Karantza 2011, Gundara et al. 2012, Wu et al. 2012). These contradictory results could be explained by considering that the actual level of autophagy in cancer cells was likely to be different in the different experimental models because of differences in the genetic and epigenetic background, and also because of the influence of stromal factors (e.g., vascularization, presence of cytokines, interactions with fibroblasts and macrophages).

Whether autophagy can represent a valuable target for the therapy of thyroid cancers remains speculative. A deeper knowledge of the mechanistic links between autophagy and thyroid carcinogenesis is expected to clarify the diagnostic and prognostic potential of autophagic-related biomarkers and could greatly contribute to a more rational use of novel therapeutic approaches based on the modulation of autophagy to cure thyroid cancers.

\section{Declaration of interest}

The authors declare that there is no conflict of interest that could be perceived as prejudicing the impartiality of the review.

\section{Funding}

Research in the laboratory of C Isidoro is supported by Comoli, Ferrari and SpA (Novara, Italy). F Morani has been supported with a PhD student fellowship granted by the 'Associazione Franca Capurro per Novara' (Italy). $\mathrm{R}$ Titone has been supported with a 'M. Di Lauro-Isidoro' fellowship granted by 'Associazione per la Ricerca Medica Ippocrate-Rhazi' (Novara, Italy) and is presently recipient of a 'Progetto Lagrange' PhD student fellowship (Cassa di Risparmio di Torino, Italy). Thyroid cancer tissues were kindly provided by $\mathrm{Dr} \mathrm{G}$ Valente (Novara, Italy).

\section{References}

Abraham D, Jackson N, Gundara JS, Zhao J, Gill AJ, Delbridge L, Robinson BG \& Sidhu SB 2011 MicroRNA profiling of sporadic and hereditary medullary thyroid cancer identifies predictors of nodal metastasis, prognosis, and potential therapeutic targets. Clinical Cancer Research 17 4772-4781. (doi:10.1158/1078-0432.CCR-11-0242)

Adler JT, Hottinger DG, Kunnimalaiyaan M \& Chen HJ 2010 Inhibition of growth in medullary thyroid cancer cells with histone deacetylase inhibitors and lithium chloride. Journal of Surgical Research 159 640-644. (doi:10.1016/j.jss.2008.08.004)

Ain KB 1998 Anaplastic thyroid carcinoma: behavior, biology, and therapeutic approaches. Thyroid 8 715-726. (doi:10.1089/thy.1998.8.715)

Akalay I, Janji B, Hasmim M, Noman MZ, André F, De Cremoux P, Bertheau P, Badoual C, Vielh P, Larsen AK et al. 2013 Epithelial-tomesenchymal transition and autophagy induction in breast carcinoma promote escape from T-cell-mediated lysis. Cancer Research 173 2418-2427. (doi:10.1158/0008-5472.CAN-12-2432)

Alers S, Löffler AS, Wesselborg S \& Stork B 2012 Role of AMPK-mTOR-Ulk1/2 in the regulation of autophagy: cross talk, shortcuts, and feedbacks. Molecular and Cellular Biology 32 2-11. (doi:10.1128/MCB.06159-11)

Alexander A, Cai SL, Kim J, Nanez A, Sahin M, MacLean KH, Inoki K, Guan KL, Shen J, Person MD et al. 2010 ATM signals to TSC2 in the cytoplasm to regulate mTORC1 in response to ROS. PNAS $\mathbf{1 0 7}$ 4153-4158. (doi:10.1073/pnas.0913860107)

Alvarez-Nuñez F, Bussaglia E, Mauricio D, Ybarra J, Vilar M, Lerma E, de Leiva A, Matias-Guiu X \& Thyroid Neoplasia Study Group 2006 PTEN promoter methylation in sporadic thyroid carcinomas. Thyroid 16 17-23. (doi:10.1089/thy.2006.16.17)

Arico S, Petiot A, Bauvy C, Dubbelhuis PF, Meijer AJ, Codogno P \& Ogier-Denis E 2001 The tumor suppressor PTEN positively regulates macroautophagy by inhibiting the phosphatidylinositol 3-kinase/protein kinase B pathway. Journal of Biological Chemistry 276 35243-35246. (doi:10.1074/jbc.C100319200)

Armstrong JL, Corazzari M, Martin S, Pagliarini V, Falasca L, Hill DS, Ellis N, Al Sabah S, Redfern CP, Fimia GM et al. 2011 Oncogenic B-RAF signaling in melanoma impairs the therapeutic advantage of autophagy inhibition. Clinical Cancer Research 17 2216-2226. (doi:10.1158/1078-0432.CCR-10-3003) http://erc.endocrinology-journals.org DOI: 10.1530/ERC-13-0271 (c) 2014 Society for Endocrinology Printed in Great Britain 
Begum S, Rosenbaum E, Henrique R, Cohen Y, Sidransky D \& Westra WH 2004 BRAF mutations in anaplastic thyroid carcinoma: implications for tumor origin, diagnosis and treatment. Modern Pathology 17 1359-1363. (doi:10.1038/modpathol.3800198)

Braun J \& Hüttelmaier S 2011 Pathogenic mechanisms of deregulated microRNA expression in thyroid carcinomas of follicular origin. Thyroid Research 4 S1. (doi:10.1186/1756-6614-4-S1-S1)

Braun J, Hoang-Vu C, Dralle H \& Huttelmaier S 2010 Downregulation of microRNAs directs the EMT and invasive potential of anaplastic thyroid carcinomas. Oncogene 29 4237-4244. (doi:10.1038/onc.2010.169)

Cahill S, Smyth P, Finn SP, Denning K, Flavin R, O'Regan EM, Li J, Potratz A, Guenther SM, Henfrey R et al. 2006 Effect of ret/PTC 1 rearrangement on transcription and post-transcriptional regulation in a papillary thyroid carcinoma model. Molecular Cancer 5 70. (doi:10.1186/ 1476-4598-5-70)

Cahill S, Smyth P, Denning K, Flavin R, Li J, Potratz A, Guenther SM, Henfrey R, O'Leary JJ \& Sheils O 2007 Effect of BRAFV600E mutation on transcription and post-transcriptional regulation in a papillary thyroid carcinoma model. Molecular Cancer 6 21. (doi:10.1186/ 1476-4598-6-21)

Castino R, Thepparit C, Bellio N, Murphy D \& Isidoro C 2008 Akt induces apoptosis in neuroblastoma cells expressing a C98X vasopressin mutant following autophagy suppression. Journal of Neuroendocrinology 20 1165-1175. (doi:10.1111/j.1365-2826.2008.01769.x)

Castino R, Fiorentino I, Cagnin M, Giovia A \& Isidoro C 2011 Chelation of lysosomal iron protects dopaminergic SH-SY5Y neuroblastoma cells from hydrogen peroxide toxicity by precluding autophagy and Akt dephosphorylation. Toxicological Sciences 123 523-541. (doi:10.1093/ toxsci/kfr179)

Catalano MG, Fortunati N, Pugliese M, Poli R, Bosco O, Mastrocola R, Aragno M \& Boccuzzi G 2006 Valproic acid, a histone deacetylase inhibitor, enhances sensitivity to doxorubicin in anaplastic thyroid cancer cells. Journal of Endocrinology 191 465-472. (doi:10.1677/ joe.1.06970)

Catalano MG, Poli R, Pugliese M, Fortunati N \& Boccuzzi G 2007 Valproic acid enhances tubulin acetylation and apoptotic activity of paclitaxel on anaplastic thyroid cancer cell lines. Endocrine-Related Cancer 14 839-845. (doi:10.1677/ERC-07-0096)

Catalano MG, Poli R, Pugliese M, Fortunati N \& Boccuzzi G 2010 Emerging molecular therapies of advanced thyroid cancer. Molecular Aspects of Medicine 31 215-226. (doi:10.1016/j.mam.2010.02.006)

Catalano MG, Fortunati N \& Boccuzzi G 2012a Epigenetics modifications and therapeutic prospects in human thyroid cancer. Frontiers in Endocrinology 3 40. (doi:10.3389/fendo.2012.00040)

Catalano MG, Fortunati N, Pugliese M, Marano F, Ortoleva L, Poli R, Asioli S, Bandino A, Palestini N, Grange C et al. 2012b Histone deacetylase inhibition modulates E-cadherin expression and suppresses migration and invasion of anaplastic thyroid cancer cells. Journal of Clinical Endocrinology and Metabolism 97 E1150-E1159. (doi:10.1210/ jc.2011-2970)

Chau NG \& Haddad RI 2013 Vandetanib for the treatment of medullary thyroid cancer. Clinical Cancer Research 19 524-529. (doi:10.1158/ 1078-0432.CCR-12-2353)

Chen N \& Karantza V 2011 Autophagy as a therapeutic target in cancer. Cancer Biology \& Therapy 11 157-168. (doi:10.4161/cbt.11.2.14622)

Chen Y \& Klionsky DJ 2011 The regulation of autophagy - unanswered questions. Journal of Cell Science 124 161-170. (doi:10.1242/jcs.064576)

Chun-Zhi Z, Lei H, An-Ling Z, Yan-Chao F, Xiao Y, Guang-Xiu W, Zhi-Fan J, Pei-Yu P, Qing-Yu Z \& Chun-Sheng K 2010 MicroRNA-221 and microRNA-222 regulate gastric carcinoma cell proliferation and radioresistance by targeting PTEN. BMC Cancer 10 367. (doi:10.1186/ 1471-2407-10-367)

Crighton D, Wilkinson S, O'Prey J, Syed N, Smith P, Harrison PR, Gasco M, Garrone O, Crook T \& Ryan KM 2006 DRAM, a p53-induced modulator of autophagy, is critical for apoptosis. Cell 126 121-134. (doi:10.1016/ j.cell.2006.05.034)
Dahia PL, Marsh DJ, Zheng Z, Zedenius J, Komminoth P, Frisk T, Wallin G, Parsons R, Longy M, Larsson C et al. 1997 Somatic deletions and mutations in the Cowden disease gene, PTEN, in sporadic thyroid tumors. Cancer Research 57 4710-4713.

Degenhardt K, Mathew R, Beaudoin B, Bray K, Anderson D, Chen G, Mukherjee C, Shi Y, Gélinas C, Fan Y et al. 2006 Autophagy promotes tumor cell survival and restricts necrosis, inflammation, and tumorigenesis. Cancer Cell 10 51-64. (doi:10.1016/j.ccr.2006.06.001)

De la Chapelle A \& Jazdzewski K 2011 MicroRNAs in thyroid cancer. Journal of Clinical Endocrinology and Metabolism 96 3326-3336. (doi:10.1210/jc.2011-1004)

Ding ZB, Shi YH, Zhou J, Qiu SJ, Xu Y, Dai Z, Shi GM, Wang XY, Ke AW et al. 2008 Association of autophagy defect with a malignant phenotype and poor prognosis of hepatocellular carcinoma. Cancer Research $\mathbf{6 8}$ 9167-9175. (doi:10.1158/0008-5472.CAN-08-1573)

Di Renzo MF, Olivero M, Ferro S, Prat M, Bongarzone I, Pilotti S, Belfiore A, Costantino A, Vigneri R, Pierotti MA et al. 1992 Overexpression of the c-MET/HGF receptor gene in human thyroid carcinomas. Oncogene $\mathbf{7}$ 2549-2553.

Egan DF, Shackelford DB, Mihaylova MM, Gelino S, Kohnz RA, Mair W, Vasquez DS, Joshi A, Gwinn DM, Taylor R et al. 2011 Phosphorylation of ULK1 (hATG1) by AMP-activated protein kinase connects energy sensing to mitophagy. Science 331 456-461. (doi:10.1126/science.1196371)

Eng C 2002 Role of PTEN, a lipid phosphatase upstream effector of protein kinase B, in epithelial thyroid carcinogenesis. Annals of the New York Academy of Sciences 968 213-221. (doi:10.1111/j.1749-6632.2002.tb04337.x)

Eskelinen EL 2005 Maturation of autophagic vacuoles in mammalian cells. Autophagy 1 1-10. (doi:10.4161/auto.1.1.1270)

Fagin JA \& Mitsiades N 2008 Molecular pathology of thyroid cancer: diagnostic and clinical implications. Best Practice \& Research. Clinical Endocrinology \& Metabolism 22 955-969. (doi:10.1016/j.beem.2008.09.017)

Fassnacht M, Kreissl MC, Weismann D \& Allolio B 2009 New targets and therapeutic approaches for endocrine malignancies. Pharmacology \& Therapeutics 123 117-141. (doi:10.1016/j.pharmthera.2009.03.013)

Fornai F, Longone P, Ferrucci M, Lenzi P, Isidoro C, Ruggieri S \& Paparelli A 2008 Autophagy and amyotrophic lateral sclerosis: the multiple roles of lithium. Autophagy 4 527-530.

Frankel LB \& Lund AH 2012 MicroRNA regulation of autophagy. Carcinogenesis 33 2018-2025. (doi:10.1093/carcin/bgs266)

Frezzetti D, Menna MD, Zoppoli P, Guerra C, Ferraro A, Bello AM, Luca PD, Calabrese C, Fusco A, Ceccarelli M et al. 2011 Upregulation of miR21 by Ras in vivo and its role in tumor growth. Oncogene 30 275-286. (doi:10.1038/onc.2010.416)

Füllgrabe J, Klionsky DJ \& Joseph B 2013 Histone post-translational modifications regulate autophagy flux and outcome. Autophagy 9 1621-1623. (doi:10.4161/auto.25803)

Fung C, Lock R, Gao S, Salas E \& Debnath J 2008 Induction of autophagy during extracellular matrix detachment promotes cell survival. Molecular Biology of the Cell 19 797-806. (doi:10.1091/mbc.E07-10-1092)

Gammoh N, Lam D, Puente C, Ganley I, Marks PA \& Jiang X 2012 Role of autophagy in histone deacetylase inhibitor-induced apoptotic and nonapoptotic cell death. PNAS 109 6561-6565. (doi:10.1073/ pnas.1204429109)

Ganley IG, Lam du H, Wang J, Ding X, Chen S \& Jiang X 2009 ULK1.ATG13.FIP200 complex mediates mTOR signaling and is essential for autophagy. Journal of Biological Chemistry $\mathbf{2 8 4}$ 12297-12305. (doi:10.1074/jbc.M900573200)

Gao W, Shen Z, Shang L \& Wang X 2011 Upregulation of human autophagy-initiation kinase ULK1 by tumor suppressor $\mathrm{p} 53$ contributes to DNA-damage-induced cell death. Cell Death and Differentiation 18 1598-1607. (doi:10.1038/cdd.2011.33)

Garcia-Rostan G, Zhao H, Camp RL, Pollan M, Herrero A, Pardo J, Wu R, Carcangiu ML, Costa J \& Tallini G 2003 ras mutations are associated with aggressive tumor phenotypes and poor prognosis in thyroid cancer. Journal of Clinical Oncology 21 3226-3235. (doi:10.1200/ JCO.2003.10.130) 
Garcia-Rostan G, Costa AM, Pereira-Castro I, Salvatore G, Hernandez R, Hermsem MJ, Herrero A, Fusco A, Cameselle-Teijeiro J \& Santoro M 2005 Mutation of the PIK3CA gene in anaplastic thyroid cancer. Cancer Research 65 10199-10207. (doi:10.1158/0008-5472.CAN-04-4259)

Garofalo M, Di Leva G, Romano G, Nuovo G, Suh SS, Ngankeu A, Taccioli C, Pichiorri F, Alder H, Secchiero P et al. 2009 miR-221\&222 regulate TRAIL resistance and enhance tumorigenicity through PTEN and TIMP3 downregulation. Cancer Cell 16 498-509. (doi:10.1016/j.ccr.2009.10.014)

Ghildiyal M \& Zamore PD 2009 Small silencing RNAs: an expanding universe. Nature Reviews. Genetics 10 94-108. (doi:10.1038/nrg2504)

Gild ML, Bullock M, Robinson BG \& Clifton-Bligh R 2011 Multikinase inhibitors: a new option for the treatment of thyroid cancer. Nature Reviews. Endocrinology 7 617-624. (doi:10.1038/nrendo.2011.141)

Gild ML, Landa I, Ryder M, Ghossein RA, Knauf JA \& Fagin JA 2013 Targeting mTOR in RET mutant medullary and differentiated thyroid cancer cells. Endocrine-Related Cancer 20 659-667. (doi:10.1530/ERC-13-0085)

Gregory PA, Bert AG, Paterson EL, Barry SC, Tsykin A, Farshid G, Vadas MA, Khew-Goodall Y \& Goodall GJ 2008 The miR-200 family and miR-205 regulate epithelial to mesenchymal transition by targeting ZEB1 and SIP1. Nature Cell Biology 10 593-601. (doi:10.1038/ncb1722)

Grodski S \& Delbridge L 2009 An update on papillary microcarcinoma. Current Opinion in Oncology 21 1-4. (doi:10.1097/CCO.0b013e32831a9a82)

Gundara JS, Robinson BG \& Sidhu SB 2011 Evolution of the "autophagamiR". Autophagy 7 1553-1554. (doi:10.4161/auto.7.12.17762)

Gundara JS, Zhao J, Robinson BG \& Sidhu SB 2012 Oncophagy: harnessing regulation of autophagy in cancer therapy. Endocrine-Related Cancer 19 R281-R295. (doi:10.1530/ERC-12-0325)

Guo JY, Chen HY, Mathew R, Fan J, Strohecker AM, Karsli-Uzunbas G, Kamphorst JJ, Chen G, Lemons JM, Karantza V et al. 2011 Activated Ras requires autophagy to maintain oxidative metabolism and tumorigenesis. Genes and Development 25 460-470. (doi:10.1101/gad.2016311)

Hamasaki M, Shibutani ST \& Yoshimori T 2013 Up-to-date membrane biogenesis in the autophagosome formation. Current Opinion in Cell Biology 25 455-460. (doi:10.1016/j.ceb.2013.03.004)

He C \& Levine B 2010 The Beclin 1 interactome. Current Opinion in Cell Biology 22 140-149. (doi:10.1016/j.ceb.2010.01.001)

He H, Jazdzewski K, Li W, Liyanarachchi S, Nagy R, Volinia S, Calin GA, Liu CG, Franssila K, Suster S et al. 2005 The role of microRNA genes in papillary thyroid carcinoma. PNAS 102 19075-19080. (doi:10.1073/pnas. 0509603102)

Hoque MO, Rosenbaum E, Westra WH, Xing M, Ladenson P, Zeiger MA, Sidransky D \& Umbricht CB 2005 Quantitative assessment of promoter methylation profiles in thyroid neoplasms. Journal of Clinical Endocrinology and Metabolism 90 4011-4018. (doi:10.1210/jc.2005-0313)

Huang X, Bai HM, Chen L, Li B \& Lu YC 2010 Reduced expression of LC3B-II and Beclin 1 in glioblastoma multiforme indicates a down-regulated autophagic capacity that relates to the progression of astrocytic tumors. Journal of Clinical Neuroscience 17 1515-1519. (doi:10.1016/j.jocn.2010. 03.051)

Huang JJ, Zhu YJ, Lin TY, Jiang WQ, Huang HQ \& Li ZM 2011 Beclin 1 expression predicts favorable clinical outcome in patients with diffuse large B-cell lymphoma treated with R-CHOP. Human Pathology $\mathbf{4 2}$ 1459-1466. (doi:10.1016/j.humpath.2010.12.014)

Huang Y, Guerrero-Preston R \& Ratovitski EA 2012 Phospho- $\Delta$ Np63 $\alpha$ dependent regulation of autophagic signaling through transcription and micro-RNA modulation. Cell Cycle 11 1247-1259. (doi:10.4161/ cc.11.6.19670)

Inoki K, Li Y, Zhu T, Wu J \& Guan KL 2002 TSC2 is phosphorylated and inhibited by Akt and suppresses mTOR signalling. Nature Cell Biology 4 648-657. (doi:10.1038/ncb839)

Iorio MV \& Croce CM 2009 MicroRNAs in cancer: small molecules with a huge impact. Journal of Clinical Oncology 27 5848-5856. (doi:10.1200/ JCO.2009.24.0317)

Janda E, Isidoro C, Carresi C \& Mollace V 2012 Defective autophagy in Parkinson's disease: role of oxidative stress. Molecular Neurobiology 46 639-661. (doi:10.1007/s12035-012-8318-1)
Jin SM, Jang HW, Sohn SY, Kim NK, Joung JY, Cho YY, Kim SW \& Chung JH 2013 Role of autophagy in the resistance to tumour necrosis factorrelated apoptosis-inducing ligand-induced apoptosis in papillary and anaplastic thyroid cancer cells. Endocrine [in press]. (doi:10.1007/ s12020-013-9997-8)

Jung CH, Jun CB, Ro SH, Kim YM, Otto NM, Cao J, Kundu M \& Kim DH 2009 ULK-Atg13-FIP200 complexes mediate mTOR signaling to the autophagy machinery. Molecular Biology of the Cell 20 1992-2003. (doi:10.1091/mbc.E08-12-1249)

Kawai A, Uchiyama H, Takano S, Nakamura N \& Ohkuma S 2007 Autophagosome-lysosome fusion depends on the $\mathrm{pH}$ in acidic compartments in CHO cells. Autophagy 3 154-157.

Kim MJ, Woo SJ, Yoon CH, Lee JS, An S, Choi YH, Hwang SG, Yoon G \& Lee SJ 2011 Involvement of autophagy in oncogenic K-Ras-induced malignant cell transformation. Journal of Biological Chemistry 286 12924-12932. (doi:10.1074/jbc.M110.138958)

Klionsky DJ, Abdalla FC, Abeliovich H, Abraham RT, Acevedo-Arozena A, Adeli K, Agholme L, Agnello M, Agostinis P, Aguirre-Ghiso JA et al. 2012 Guidelines for the use and interpretation of assays for monitoring autophagy. Autophagy 8 445-544. (doi:10.4161/auto.19496)

Knauf JA, Kuroda H, Basu S \& Fagin JA 2003 RET/PTC-induced dedifferentiation of thyroid cells is mediated through Y1062 signaling through SHC-RAS-MAP kinase. Oncogene 22 4406-4412. (doi:10.1038/ sj.onc.1206602)

Koukourakis MI, Giatromanolaki A, Sivridis E, Pitiakoudis M, Gatter KC \& Harris AL 2010 Beclin 1 over- and underexpression in colorectal cancer: distinct patterns relate to prognosis and tumour hypoxia. British Journal of Cancer 103 1209-1214. (doi:10.1038/sj.bjc.6605904)

Kovaleva V, Mora R, Park YJ, Plass C, Chiramel AI, Bartenschlager R, Döhner H, Stilgenbauer S, Pscherer A, Lichter P et al. 2012 miRNA-130a targets ATG2B and DICER1 to inhibit autophagy and trigger killing of chronic lymphocytic leukemia cells. Cancer Research 72 1763-1772. (doi:10.1158/0008-5472.CAN-11-3671)

Kroemer G, Mariño G \& Levine B 2010 Autophagy and the integrated stress response. Molecular Cell 22 280-293. (doi:10.1016/j.molcel. 2010.09.023)

Lee IH, Cao L, Mostoslavsky R, Lombard DB, Liu J, Bruns NE, Tsokos M, Alt FW \& Finkel T 2008 A role for the NAD-dependent deacetylase Sirt1 in the regulation of autophagy. PNAS 105 3374-3379. (doi:10.1073/pnas.0712145105)

Lee JY, Koga H, Kawaguchi Y, Tang W, Wong E, Gao YS, Pandey UB, Kaushik S, Tresse E, Lu J et al. 2010 TP: HDAC6 controls autophagosome maturation essential for ubiquitin-selective quality control autophagy. EMBO Journal 29 969-980. (doi:10.1038/emboj.2009.405)

Li BX, Li CY, Peng RQ, Wu XJ, Wang HY, Wan DS, Zhu XF \& Zhang XS 2009 The expression of beclin 1 is associated with favorable prognosis in stage IIIB colon cancers. Autophagy 5 303-306. (doi:10.4161/auto.5.3.7491)

Liang XH, Jackson S, Seaman M, Brown K, Kempkes B, Hibshoosh H \& Levine B 1999 Induction of autophagy and inhibition of tumorigenesis by beclin 1. Nature 402 672-676. (doi:10.1038/45257)

Lim SM, Chang H, Yoon MJ, Hong YK, Kim H, Chung WY, Park CS, Nam KH, Kang SW, Kim MK et al. 2013 A multicenter, phase II trial of everolimus in locally advanced or metastatic thyroid cancer of all histologic subtypes. Annals of Oncology [in press]. (doi:10.1093/ annonc/mdt379)

Lin CI, Whang EE, Abramson MA, Jiang X, Price BD, Donner DB, Moore FD Jr \& Ruan DT 2009 Autophagy: a new target for advanced papillary thyroid cancer therapy. Surgery 146 1208-1214. (doi:10.1016/j.surg. 2009.09.019)

Lin CI, Whang EE, Donner DB, Du J, Lorch J, He F, Jiang X, Price BD, Moore FD Jr \& Ruan DT 2010 Autophagy induction with RAD001 enhances chemosensitivity and radiosensitivity through Met inhibition in papillary thyroid cancer. Molecular Cancer Research $\mathbf{8}$ 1217-1226. (doi:10.1158/1541-7786.MCR-10-0162)

Lin CI, Whang EE, Lorch JH \& Ruan DT 2012a Autophagic activation potentiates the antiproliferative effects of tyrosine kinase inhibitors 
in medullary thyroid. Surgery 152 1142-1149. (doi:10.1016/j.surg. 2012.08.016)

Lin SY, Li TY, Liu Q, Zhang C, Li X, Chen Y, Zhang SM, Lian G, Liu Q, Ruan K et al. 2012b GSK3-TIP60-ULK1 signaling pathway links growth factor deprivation to autophagy. Science 336 477-481. (doi:10.1126/ science.1217032)

Liu Y, Yang Y, Ye YC, Shi QF, Chai K, Tashiro S, Onodera S \& Ikejima T 2012 Activation of ERK-p53 and ERK-mediated phosphorylation of Bcl-2 are involved in autophagic cell death induced by the c-Met inhibitor SU11274 in human lung cancer A549 cells. Journal of Pharmacological Sciences 8 423-432. (doi:10.1254/jphs.11181FP)

Lu Z, Luo RZ, Lu Y, Zhang X, Yu Q, Khare S, Kondo S, Kondo Y, Yu Y, Mills GB et al. 2008 The tumor suppressor gene ARHI regulates autophagy and tumor dormancy in human ovarian cancer cells. Journal of Clinical Investigation 118 3917-3929. (doi:10.1172/JCI35512)

Lu CH, Liu YW, Hua SC, Yu HI, Chang YP \& Lee YR 2012 Autophagy induction of reversine on human follicular thyroid cancer cells. Biomedicine \& Pharmacotherapy 66 642-647. (doi:10.1016/j.biopha. 2012.08.001)

Maddodi N, Huang W, Havighurst T, Kim K, Longley BJ \& Setaluri V 2010 Induction of autophagy and inhibition of melanoma growth in vitro and in vivo by hyperactivation of oncogenic BRAF. Journal of Investigative Dermatology 130 1657-1667. (doi:10.1038/jid.2010.26)

Maiuri MC, Tasdemir E, Criollo A, Morselli E, Vicencio JM, Carnuccio R \& Kroemer G 2009 Control of autophagy by oncogenes and tumor suppressor genes. Cell Death and Differentiation 16 87-93. (doi:10.1038/ cdd.2008.131)

Maiuri MC, Galluzzi L, Morselli E, Kepp O, Malik SA \& Kroemer G 2010 Autophagy regulation by p53. Current Opinion in Cell Biology 22 181-185. (doi:10.1016/j.ceb.2009.12.001)

Mehrpour M, Esclatine A, Beau I \& Codogno P 2010 Overview of macroautophagy regulation in mammalian cells. Cell Research 20 748-762. (doi:10.1038/cr.2010.82)

Mineo R, Costantino A, Frasca F, Sciacca L, Russo S, Vigneri R \& Belfiore A 2004 Activation of the hepatocyte growth factor (HGF)-Met system in papillary thyroid cancer: biological effects of HGF in thyroid cancer cells depend on Met expression levels. Endocrinology 145 4355-4365. (doi:10.1210/en.2003-1762)

Mizushima N \& Komatsu M 2011 Autophagy: renovation of cells and tissues. Cell 11 728-741. (doi:10.1016/j.cell.2011.10.026)

Mizushima N, Yoshimori T \& Ohsumi Y 2011 The role of Atg proteins in autophagosome formation. Annual Review of Cell Biology 27 107-132. (doi:10.1146/annurev-cellbio-092910-154005)

Moresi V, Carrer M, Grueter CE, Rifki OF, Shelton JM, Richardson JA, Bassel-Duby R \& Olson EN 2012 Histone deacetylases 1 and 2 regulate autophagy flux and skeletal muscle homeostasis in mice. PNAS 109 1649-1654. (doi:10.1073/pnas.1121159109)

Motoi N, Sakamoto A, Yamochi T, Horiuchi H, Motoi T \& Machinami R 2000 Role of ras mutation in the progression of thyroid carcinoma of follicular epithelial origin. Pathology, Research and Practice 196 1-7. (doi:10.1016/S0344-0338(00)80015-1)

Nicotra G, Mercalli F, Peracchio C, Castino R, Follo C, Valente G \& Isidoro C 2010 Autophagy-active beclin-1 correlates with favourable clinical outcome in non-Hodgkin lymphomas. Modern Pathology 23 937-950. (doi:10.1038/modpathol.2010.80)

Nikiforova MN \& Nikiforov YE 2009 Molecular diagnostics and predictors in thyroid cancer. Thyroid 19 1351-1361. (doi:10.1089/thy.2009.0240)

Nikiforova MN, Kimura ET, Gandhi M, Biddinger PW, Knauf JA, Basolo F, Zhu Z, Giannini R, Salvatore G, Fusco A et al. 2003 BRAF mutations in thyroid tumors are restricted to papillary carcinomas and anaplastic or poorly differentiated carcinomas arising from papillary carcinomas. Journal of Clinical Endocrinology and Metabolism 88 5399-5404. (doi:10.1210/jc.2003-030838)

Noda T, Matsunaga K, Taguchi-Atarashi N \& Yoshimori T 2010 Regulation of membrane biogenesis in autophagy via PI3P dynamics. Seminars in Cell \& Developmental Biology 21 671-676. (doi:10.1016/j.semcdb. 2010.04.002)

Noguchi H, Yamashita H, Murakami T, Hirai K, Noguchi Y, Maruta J, Yokoi T \& Noguchi S 2009 Successful treatment of anaplastic thyroid carcinoma with a combination of oral valproic acid, chemotherapy, radiation and surgery. Endocrine Journal 56 245-249. (doi:10.1507/ endocrj.K08E-016)

Ogier-Denis E, Couvineau A, Maoret JJ, Houri JJ, Bauvy C, De Stefanis D, Isidoro C, Laburthe M \& Codogno P 1995 A heterotrimeric Gi3-protein controls autophagic sequestration in the human colon cancer cell line HT-29. Journal of Biological Chemistry 270 13-16. (doi:10.1074/ jbc.270.1.13)

Ogier-Denis E, Pattingre S, El Benna J \& Codogno P 2000 Erk1/2-dependent phosphorylation of Galpha-interacting protein stimulates its GTPase accelerating activity and autophagy in human colon cancer cells. Journal of Biological Chemistry 275 39090-39095. (doi:10.1074/ jbc.M006198200)

Orenstein SJ \& Cuervo AM 2010 Chaperone-mediated autophagy: molecular mechanisms and physiological relevance. Seminars in Cell \& Developmental Biology 21 719-726. (doi:10.1016/j.semcdb.2010.02.005)

Pallante P, Visone R, Ferracin M, Ferraro A, Berlingieri MT, Troncone G, Chiappetta G, Liu CG, Santoro M, Negrini M et al. 2006 MicroRNA deregulation in human thyroid papillary carcinomas. Endocrine-Related Cancer 13 497-508. (doi:10.1677/erc.1.01209)

Pallante P, Visone R, Croce CM \& Fusco A 2010 Deregulation of microRNA expression in follicular-cell-derived human thyroid carcinomas. Endocrine-Related Cancer 17 91-104. (doi:10.1677/ERC-09-0217)

Park SM, Gaur AB, Lengyel E \& Peter ME 2008 The miR-200 family determines the epithelial phenotype of cancer cells by targeting the E-cadherin repressors ZEB1 and ZEB2. Genes and Development 22 894-907. (doi:10.1101/gad.1640608)

Pattingre S, Tassa A, Qu X, Garuti R, Liang XH, Mizushima N, Packer M, Schneider MD \& Levine B 2005 Bcl-2 antiapoptotic proteins inhibit Beclin 1-dependent autophagy. Cell 122 927-939. (doi:10.1016/ j.cell.2005.07.002)

Petiot A, Ogier-Denis E, Blommaart EF, Meijer AJ \& Codogno P 2000 Distinct classes of phosphatidylinositol $3^{\prime}$-kinases are involved in signaling pathways that control macroautophagy in HT-29 cells. Journal of Biological Chemistry 275 992-998. (doi:10.1074/ jbc.275.2.992)

Pirtoli L, Cevenini G, Tini P, Vannini M, Oliveri G, Marsili S, Mourmouras V Rubino G \& Miracco C 2009 The prognostic role of Beclin 1 protein expression in high-grade gliomas. Autophagy 5 930-936. (doi:10.4161/ auto.5.7.9227)

Qu X, Yu J, Bhagat G, Furuya N, Hibshoosh H, Troxel A, Rosen J, Eskelinen EL, Mizushima N, Ohsumi Y et al. 2003 Promotion of tumorigenesis by heterozygous disruption of the beclin 1 autophagy gene. Journal of Clinical Investigation 112 1809-1820. (doi:10.1172/JCI200320039)

Ramirez R, Hsu D, Patel A, Fenton C, Dinauer C, Tuttle RM \& Francis GL 2000 Over-expression of hepatocyte growth factor/scatter factor (HGF/SF) and the HGF/SF receptor (cMET) are associated with a high risk of metastasis and recurrence for children and young adults with papillary thyroid carcinoma. Clinical Endocrinology 53 635-644. (doi:10.1046/j.1365-2265.2000.01124.x)

Ravikumar B, Sarkar S, Davies JE, Futter M, Garcia-Arencibia M, Green-Thompson ZW, Jimenez-Sanchez M, Korolchuk VI, Lichtenberg M, Luo S et al. 2010 Regulation of mammalian autophagy in physiology and pathophysiology. Physiological Reviews 90 1383-1435. (doi:10.1152/physrev.00030.2009)

Ringel MD, Hayre N, Saito J, Saunier B, Schuppert H, Burch F, Bernet V, Burman KD, Kohn LD \& Saji M 2001 Overexpression and overactivation of Akt in thyroid carcinoma. Cancer Research 61 6105-6111.

Robert T, Vanoli F, Chiolo I, Shubassi G, Bernstein KA, Rothstein R, Botrugno OA, Parazzoli D, Oldani A, Minucci S et al. 2011 HDACs link the DNA damage response, processing of double-strand breaks and autophagy. Nature 471 74-79. (doi:10.1038/nature09803) 
Rodriguez-Rocha H, Garcia-Garcia A, Panayiotidis MI \& Franco R 2011 DNA damage and autophagy. Mutation Research 711 158-166. (doi:10.1016/ j.mrfmmm.2011.03.007)

Roman S, Lin R \& Sosa JA 2006 Prognosis of medullary thyroid carcinoma:demographic, clinical, and pathologic predictors of survival in 1252 cases. Cancer 107 2134-2142. (doi:10.1002/cncr.22244)

Rubinsztein DC, Shpilka T \& Elazar Z 2012 Mechanisms of autophagosome biogenesis. Current Biology 22 R29-R34. (doi:10.1016/j.cub.2011.11.034)

Russo D, Damante G, Puxeddu E, Durante C \& Filetti S 2011 Epigenetics of thyroid cancer and novel therapeutic targets. Journal of Molecular Endocrinology 46 R73-R81. (doi:10.1530/JME-10-0150)

Sahu R, Kaushik S, Clement CC, Cannizzo ES, Scharf B, Follenzi A, Potolicchio I, Nieves E, Cuervo AM \& Santambrogio L 2011 Microautophagy of cytosolic proteins by late endosomes. Developmental Cell 20 131-139. (doi:10.1016/j.devcel.2010.12.003)

Sancak Y, Bar-Peled L, Zoncu R, Markhard AL, Nada S \& Sabatini DM 2010 Ragulator-Rag complex targets mTORC1 to the lysosomal surface and is necessary for its activation by amino acids. Cell 141 290-303. (doi:10.1016/j.cell.2010.02.024)

Santoro M, Melillo RM, Carlomagno F, Vecchio G \& Fusco A 2004 Minireview. RET:normal and abnormal functions. Endocrinology 145 5448-5451. (doi:10.1210/en.2004-0922)

Schnekenburger M, Grandjenette C, Ghelfi J, Karius T, Foliguet B, Dicato M \& Diederich M 2011 Sustained exposure to the DNA demethylating agent, 2 '-deoxy-5-azacytidine, leads to apoptotic cell death in chronic myeloid leukemia by promoting differentiation, senescence, and autophagy. Biochemical Pharmacology 81 364-378. (doi:10.1016/ j.bcp.2010.10.013)

Schwertheim S, Sheu SY, Worm K, Grabellus F \& Schmid KW 2009 Analysis of deregulated miRNAs is helpful to distinguish poorly differentiated thyroid carcinoma from papillary thyroid carcinoma. Hormone and Metabolic Research 41 475-481. (doi:10.1055/s-0029-1215593)

Shao Y, Gao Z, Marks PA \& Jiang X 2004 Apoptotic and autophagic cell death induced by histone deacetylase inhibitors. PNAS $\mathbf{1 0 1}$ 18030-18035. (doi:10.1073/pnas.0408345102)

Sheu SY, Grabellus F, Schwertheim S, Worm K, Broecker-Preuss M \& Schmid KW 2010 Differential miRNA expression profiles in variants of papillary thyroid carcinoma and encapsulated follicular thyroid tumours. British Journal of Cancer 102 376-382. (doi:10.1038/sj.bjc.6605493)

Shinohara M, Chung YJ, Saji M \& Singel M 2007 AKT in thyroid tumorigenesis and progression. Endocrinology 148 942-947. (doi:10.1210/en.2006-0937)

Siegel R, Naishadham D \& Jemal A 2013 Cancer statistics, 2013. CA: A Cancer Journal for Clinicians 63 11-30. (doi:10.3322/caac.21166)

Smallridge RC 2012 Approach to the patient with anaplastic thyroid carcinoma. Journal of Clinical Endocrinology and Metabolism 97 2566-2572. (doi:10.1210/jc.2012-1314)

Smallridge RC, Marlow LA \& Copland JA 2009 Anaplastic thyroid cancer: molecular pathogenesis and emerging therapies. Endocrine-Related Cancer 16 17-44. (doi:10.1677/ERC-08-0154)

Smallridge RC, Ain KB, Asa SL, Bible KC, Brierley JD, Burman KD, Kebebew E, Lee NY, Nikiforov YE, Rosenthal MS et al. 2012 American Thyroid Association guidelines for management of patients with anaplastic thyroid cancer. Thyroid 22 1104-1139. (doi:10.1089/thy.2012.0302)

Stella GM, Benvenuti S \& Comoglio PM 2010 Targeting the MET oncogene in cancer and metastases. Expert Opinion on Investigational Drugs 19 1381-1394. (doi:10.1517/13543784.2010.522988)

Takano T, Ito Y, Hirokawa M, Yoshida H \& Miyauchi A 2007 BRAF V600E mutation in anaplastic thyroid carcinomas and their accompanying differentiated carcinomas. British Journal of Cancer 96 1549-1553. (doi:10.1038/sj.bjc.6603764)

Tekirdag KA, Korkmaz G, Ozturk DG, Agami R \& Gozuacik D 2013 MIR181A regulates starvation- and rapamycin-induced autophagy through targeting of ATG5. Autophagy 9 374-385. (doi:10.4161/ auto.23117)
Tetzlaff MT, Liu A, Xu X, Master SR, Baldwin DA, Tobias JW, Livolsi VA \& Baloch ZW 2007 Differential expression of miRNAs in papillary thyroid carcinoma compared to multinodular goiter using formalin fixed paraffin embedded tissues. Endocrine Pathology 18 163-173. (doi:10.1007/s12022-007-0023-7)

Thornton K, Kim G, Maher VE, Chattopadhyay S, Tang S, Moon YJ, Song P, Marathe A, Balakrishnan S, Zhu H et al. 2012 Vandetanib for the treatment of symptomatic or progressive medullary thyroid cancer in patients with unresectable locally advanced or metastatic disease: U.S. Food and Drug Administration drug approval summary. Clinical Cancer Research 18 3722-3730. (doi:10.1158/1078-0432.CCR-12-0411)

Timp W \& Feinberg AP 2013 Cancer as a dysregulated epigenome allowing cellular growth advantage at the expense of the host. Nature Reviews. Cancer 13 497-510. (doi:10.1038/nrc3486)

Tooze SA \& Yoshimori T 2010 The origin of the autophagosomal membrane. Nature Cell Biology 12 831-835. (doi:10.1038/ncb0910-831)

True O \& Matthias P 2012 Interplay between histone deacetylases and autophagy - from cancer therapy to neurodegeneration. Immunology and Cell Biology 90 78-84. (doi:10.1038/icb.2011.103)

Visone R, Russo L, Pallante P, De Martino I, Ferraro A, Leone V, Borbone E, Petrocca F, Alder H, Croce CM et al. 2007 MicroRNAs (miR)-221 and miR-222, both overexpressed in human thyroid papillary carcinomas, regulate p27Kip1 protein levels and cell cycle. Endocrine-Related Cancer 14 791-798. (doi:10.1677/ERC-07-0129)

Wang Y, Hou P, Yu H, Wang W, Ji M, Zhao S, Yan S, Sun X, Liu D, Shi B et al. 2007 High prevalence and mutual exclusivity of genetic alterations in the phosphatidylinositol-3-kinase/Akt pathway in thyroid tumors. Journal of Clinical Endocrinology and Metabolism 92 2387-2390. (doi:10.1210/jc.2006-2019)

Wang RC, Wei Y, An Z, Zou Z, Xiao G, Bhagat G, White M, Reichelt J \& Levine B 2012 Akt-mediated regulation of autophagy and tumorigenesis through Beclin 1 phosphorylation. Science 338 956-959. (doi:10.1126/science.1225967)

Weber F, Aldred MA, Morrison CD, Plass C, Frilling A, Broelsch CE, Waite KA \& Eng C 2005 Silencing of the maternally imprinted tumor suppressor ARHI contributes to follicular thyroid carcinogenesis. Journal of Clinical Endocrinology and Metabolism 90 1149-1155. (doi:10.1210/jc.2004-1447)

White E \& Di Paola RS 2009 The double-edged sword of autophagy modulation in cancer. Clinical Cancer Research 15 5308-5316. (doi:10.1158/1078-0432.CCR-07-5023)

Won KY, Kim GY, Lim SJ \& Kim YW 2012 Decreased Beclin-1 expression is correlated with the growth of the primary tumor in patients with squamous cell carcinoma and adenocarcinoma of the lung. Human Pathology 43 62-68. (doi:10.1016/j.humpath.2011.04.007)

Wong PM, Puente C, Ganley IG \& Jiang X 2013 The ULK1 complex: sensing nutrient signals for autophagy activation. Autophagy 9 124-137. (doi:10.4161/auto.23323)

Wu G, Mambo E, Guo Z, Hu S, Huang X, Gollin SM, Trink B, Ladenson PW, Sidransky D \& Xing M 2005 Uncommon mutation, but common amplifications, of the PIK3CA gene in thyroid tumors. Journal of Clinical Endocrinology and Metabolism 90 4688-4693. (doi:10.1210/ jc.2004-2281)

Wu WK, Coffelt SB, Cho CH, Wang XJ, Lee CW, Chan FK, Yu J \& Sung JJ 2012 The autophagic paradox in cancer therapy. Oncogene 31 939-953. (doi:10.1038/onc.2011.295)

Wu XY, Chen J, Cao QH, Dong M, Lin Q, Fan XJ, Xia Q, Chen ZH, Liu Q \& Wan XB 2013 Beclin 1 activation enhances chemosensitivity and predicts a favorable outcome for primary duodenal adenocarcinoma. Tumour Biology 34 713-722. (doi:10.1007/s13277-012-0599-5)

Xing M 2007 BRAF mutation in papillary thyroid cancer: pathogenic role, molecular bases, and clinical implications. Endocrine Reviews $\mathbf{2 8}$ 742-762. (doi:10.1210/er.2007-0007)

Yang Z \& Klionsky DJ 2010 Eaten alive: a history of macroautophagy. Nature Cell Biology 12 814-822. (doi:10.1038/ncb0910-814) 
Yang ZJ, Chee CE, Huang S \& Sinicrope FA 2011 The role of autophagy in cancer: therapeutic implications. Molecular Cancer Therapeutics 10 1533-1541. (doi:10.1158/1535-7163.MCT-11-0047)

Yang X, Zhong X, Tanyi JL, Shen J, Xu C, Gao P, Zheng TM, DeMichele A \& Zhang L 2013 mir-30d regulates multiple genes in the autophagy pathway and impairs autophagy process in human cancer cells. Biochemical and Biophysical Research Communications 431 617-622. (doi:10.1016/j.bbrc.2012.12.083)

Yeung SC, She M, Yang H, Pan J, Sun L \& Chaplin D 2007 Combination chemotherapy including combretastatin A4 phosphate and paclitaxel is effective against anaplastic thyroid cancer in a nude mouse xenograft model. Journal of Clinical Endocrinology and Metabolism 92 2902-2909. (doi:10.1210/jc.2007-0027)

Yi C, Ma M, Ran L, Zheng J, Tong J, Zhu J, Ma C, Sun Y, Zhang S, Feng W et al. 2012 Function and molecular mechanism of acetylation in autophagy regulation. Science 336 474-477. (doi:10.1126/science. 1216990)
Yue Z, Jin S, Yang C, Levine AJ \& Heintz N 2003 Beclin 1, an autophagy gene essential for early embryonic development, is a haploinsufficient tumor suppressor. PNAS 100 15077-15082. (doi:10.1073/pnas.2436255100)

Zalckvar E, Berissi H, Mizrachy L, Idelchuk Y, Koren I, Eisenstein M, Sabanay H, Pinkas-Kramarski R \& Kimchi A 2009 DAP-kinase-mediated phosphorylation on the BH3 domain of beclin 1 promotes dissociation of beclin 1 from Bcl- XL and induction of autophagy. EMBO Reports $\mathbf{1 0}$ 285-292. (doi:10.1038/embor.2008.246)

Zeybek ND, Gulcelik NE, Kaymaz FF, Sarisozen C, Vural I, Bodur E, Canpinar H, Usman A \& Asan E 2011 Rosuvastatin induces apoptosis in cultured human papillary thyroid cancer cells. Journal of Endocrinology 210 105-115. (doi:10.1530/JOE-10-0411)

Zhai H, Fesler A \& Ju J 2013 MicroRNA: a third dimension in autophagy. Cell Cycle 12 246-250. (doi:10.4161/cc.23273)

Zhu H, Wu H, Liu X, Li B, Chen Y, Ren X, Liu CG \& Yang JM 2009 Regulation of autophagy by a beclin 1-targeted microRNA, miR-30a, in cancer cells. Autophagy 5 816-823.

Received in final form 15 October 2013

Accepted 22 October 2013

Made available online as an Accepted Preprint

25 October 2013 http://erc.endocrinology-journals.org DOI: $10.1530 /$ ERC-13-0271
(C) 2014 Society for Endocrinology Printed in Great Britain
Published by Bioscientifica Ltd. 